\title{
A Narrative Synthesis Review of Out-of-Pocket Payments for Health Services Under Insurance Regimes: A Policy Implementation Gap Hindering Universal Health Coverage in Sub-Saharan Africa
}

\author{
Abigail Nyarko Codjoe Derkyi-Kwarteng ${ }^{1,2^{*}}$, Irene Akua Agyepong ${ }^{1,3}$, Nana Enyimayew ${ }^{1}$, Lucy Gilson $^{4,5}$
}

\begin{abstract}
Background: "Achieve universal health coverage (UHC), including financial risk protection, access to quality essential healthcare services and access to safe, effective, quality and affordable essential medicines and vaccines for all" is the Sustainable Development Goal (SDG) 3.8 target. Although most high-income countries have achieved or are very close to this target, low- and middle-income countries (LMICs) especially those in sub-Saharan Africa (SSA) are still struggling with its achievement. One of the observed challenges in SSA is that even where services are supposed to be "free" at point-of-use because they are covered by a health insurance scheme, out-of-pocket fees are sometimes being made by clients. This represents a policy implementation gap. This study sought to synthesise the known evidence from the published literature on the 'what' and 'why' of this policy implementation gap in SSA.

Methods: The study drew on Lipsky's street level bureaucracy (SLB) theory, the concept of practical norms, and Taryn Vian's framework of corruption in the health sector to explore this policy implementation gap through a narrative synthesis review. The data from selected literature were extracted and synthesized iteratively using a thematic content analysis approach.

Results: Insured clients paid out-of-pocket for a wide range of services covered by insurance policies. They made formal and informal cash and in-kind payments. The reasons for the payments were complex and multifactorial, potentially explained in many but not all instances, by coping strategies of street level bureaucrats to conflicting health sector policy objectives and resource constraints. In other instances, these payments appeared to be related to structural violence and the 'corruption complex' governed by practical norms.

Conclusion: A continued top-down approach to health financing reforms and UHC policy is likely to face implementation gaps. It is important to explore bottom-up approaches - recognizing issues related to coping behaviour and practical norms in the face of unrealistic, conflicting policy dictates.

Keywords: Policy Implementation Gap, Universal Health Coverage, Out-of-Pocket Payments, Health Insurance, SubSaharan Africa, Low- and Middle-Income Countries

Copyright: @ 2021 The Author(s); Published by Kerman University of Medical Sciences. This is an open-access article distributed under the terms of the Creative Commons Attribution License (http://creativecommons.org/licenses/ by/4.0), which permits unrestricted use, distribution, and reproduction in any medium, provided the original work is properly cited.

Citation: Derkyi-Kwarteng ANC, Agyepong IA, Enyimayew N, Gilson L. A narrative synthesis review of out-of-pocket payments for health services under insurance regimes: a policy implementation gap hindering universal health coverage in sub-Saharan Africa. Int J Health Policy Manag. 2021;10(7):443-461. doi:10.34172/ijhpm.2021.38
\end{abstract}

\section{Article History:}

Received: 20 September 2020 Accepted: 10 April 2021 ePublished: 1 May 2021

\section{Background}

Sustainable Development Goal (SDG) 3 has as one of its key targets, "Achieve universal health coverage (UHC), including financial risk protection, access to quality essential healthcare services and access to safe, effective, quality, affordable essential medicines and vaccines for all." At the heart of this concept are the values of social justice and health as a human right. To achieve universal primary healthcare coverage, countries require systems with values that "put people at the centre of healthcare"1 and ensure that all people can have the health services they need without suffering catastrophic payments at point-of-service use. Countries must mobilise sufficient funds, decrease out-of-pocket payments for health services, and improve equity and efficiency. ${ }^{2}$ Most high- income countries have attained a reasonable semblance of UHC. All the high-income countries that have managed to do this have relied largely on public financing arrangements rather than private-for-profit health insurance. Evidence from Organisation for Economic Co-operation and Development (OECD) countries shows that private-for-profit insurance while increasing health system resources and consumer choice has equity challenges and tends to raise healthcare expenditure. ${ }^{3}$ The UHC goal remains a challenge for most low- and middle-income countries (LMICs). ${ }^{4,5}$ Only a few LMICs such as Thailand ${ }^{6}$ and Costa Rica have attained UHC, relying on public financing rather than private-for-profit insurance. $^{7,8}$

Globally, the UHC financing arrangements in most 
countries involve some form of pre-payment from general taxes, insurance premiums or a mix. We use the term "Health Insurance" in this paper to refer to health financing protection from out-of-pocket payments at point-of-service use arrangements that involve both pre-payment and risk pooling regardless of whether the source of funding is general taxes, insurance premiums or a mix. ${ }^{9}$ The OECD proposals for a taxonomy of health insurance arrangements use four main criteria namely, whether: the sources of scheme financing are public or private, the scheme is mandatory or compulsory, participation is on group or individual basis and how the premium is calculated. Public as well as private health insurance schemes can be voluntary or mandatory. Public health insurance schemes are mainly financed through general taxation, mandatory payroll levies and contributions to social security schemes or some combination of the three. The terminology of public health insurance schemes generally overlaps in meaning with the terminology of social health insurance schemes. ${ }^{10}$ Private-for-profit health insurance schemes are predominantly financed through private premiums paid by individuals or groups. A diversity of insurance arrangements exists under the classification of private insurance. Sometimes the boundaries between public and private insurance are blurred with some schemes classified as private-not-for-profit being to large extent social health insurance type schemes in their objectives and financing arrangements. ${ }^{11,12}$ Community health insurance schemes are a form of largely grassroots based health insurance arrangements that often use a combination of public and private-not-for-profit insurance arrangements; that have emerged in LMICs. ${ }^{13}$ Our focus in this review is on all types of health insurance schemes in sub-Saharan Africa (SSA), whether public, private, community health insurance or a combination.

By definition, an out-of-pocket payment for health is a fee paid directly by clients to healthcare providers at the point-of-service use. ${ }^{14}$ Commonly in the literature they are classified as formal and informal. This refers to whether payments are clearly receipted and accounted for as part of the legally authorized systems of fee payment in the health system (formal) or not (informal). In this paper, we expand this terminology because it does not adequately cover all our observations and analysis.

Specifically, we use the terminology of 'central-policyintended' and 'central-policy-unintended' as well as 'peripheralpolicy-intended' and 'peripheral-policy-unintended' to qualify the terminology of formal and informal. 'Central-policyintended' refers to payments that are formally sanctioned as part of central-level policy and/or accompanying legislation, administrative rules and procedures in the health system. Central-policy-unintended payments are not sanctioned by the national level policy in its statements, accompanying legislation, administrative rules and procedures.

We use this terminology to distinguish central-level-policy from street level or frontline worker and manager policy. Strictly speaking street level or frontline worker and manager user fee policies not sanctioned by the centre are 'informal' payments. However, we found such payments were sometimes formalized, documented in local 'policy' statements, receipted in some way or the other and 'formally' managed at the periphery. They represented coping behaviour rather than corruption. At the same time, we found that central-policyintended payments could still be converted into informal payments that are more or less explained by corruption. For example, the situation where health workers collect centralpolicy-intended fees into their pockets for personal gain and fail to issue receipts. This can happen with poor daytime supervision or during the night when due to poor human resource strength, health facilities cannot provide finance staff for night duties to collect revenue as experienced in some LMIC health facilities. Payments are not receipted accordingly into notional revenue books.

Out-of-pocket payments at point-of-service use especially when large, relative to incomes; are undesirable from an equity and right to health perspective. They potentially lead to catastrophic health expenditure (CHE) especially among the poorest and most vulnerable. $\mathrm{Xu}$ et $\mathrm{al}^{15}$ analysed household health expenditure in over 50 countries and documented that prepayments and risk pooling for national health system financing through social insurance or general taxes decreases out-of-pocket health payments and prevents CHE. On the other hand, a review of studies in LMICs ${ }^{16-41}$ shows that outof-pocket payments at point-of-service use, irrespective of the context (eg, absence of health insurance, ${ }^{16,17,25,26,37,40,41}$ community-based health insurance, ${ }^{23}$ private-for-profit health insurance, ${ }^{24}$ national health insurance, ${ }^{35,36,38,39}$ maternal health, ${ }^{18,21}$ mental health, ${ }^{20}$ child health, ${ }^{19,21,33}$ surgical care, ${ }^{34}$ or non-communicable disease ${ }^{22,29,30}$ ) decrease access to health services and increase CHE for households.

Most OECD countries provide some form of near UHC whether through health insurance, taxation or a mix for almost all their citizens. ${ }^{42}$ In these countries, out-of-pocket payments are central-policy-intended and often take the form of co-payment, deductibles, co-insurance and payment for services not covered by the health insurance. ${ }^{43}$ They are generally designed to form relatively small percentages of total health expenditure. ${ }^{44,45}$ In LMICs, central-policy-intended out-of-pocket payments also exist. They may sometimes form relatively large percentages of the total health expenditure, ranging from under $10 \%$ in Malawi to over $90 \%$ in China. ${ }^{46}$ These central-policy-intended out-of-pocket payments cover health services and medicines. ${ }^{46}$ They may be a major financing mechanism rather than part of an insurance system. An example is the central-policy-intended co-payment in Rwanda's health insurance system by relatively high-income groups for non-primary services not covered by health insurance. The poorest are exempt from these payments. ${ }^{47}$

In Kyrgyzstan, Murphy et $\mathrm{al}^{48}$ reported that out-ofpocket payments, as co-pays for medicines not covered by the Additional Drug Package of the 1996 mandatory health insurance reform, resulted in poor adherence to antihypertensive medication and caused CHE for the poor. A 2013 study by Barasa et al in Kenya documented the negative effects of direct and indirect out-of-pocket payments for healthcare. ${ }^{16}$ Studies in India, Taiwan and China ${ }^{49-51}$ have shown that out-of-pocket payments cause CHE, especially for 
the poor.

"Central-policy-unintended payments" have been described as "unofficial," "informal," "illegal," "rent," "outof-pocket payments" and "corruption." It is a topic that is sometimes discussed gingerly because it has complex implicit and explicit power strings and interconnections, which if addressed cursorily, could lead to a cascade of unintended consequences for the health system. In recent times, there is the growing call to more overtly talk about corruption in the health system towards equitably achieving UHC. ${ }^{52-54}$

Some studies have sought to understand central-policyunintended out-of-pocket payments in the health systems of Iran, ${ }^{55}$ Bangladesh, ${ }^{56}$ Nigeria, ${ }^{57}$ Myanmar ${ }^{18}$ and India ${ }^{58}$ under rent-seeking and informal payments. Other studies cursorily imply the existence of central-policy-unintended payments in health systems of Uganda, ${ }^{34}$ Ukraine, ${ }^{59}$ Ghana, ${ }^{60,61}$ and in 36 LMICs reviewed for acceptability, accessibility, availability and quality of maternal, reproductive and child health services ${ }^{62}$ without focusing on an in-depth exploration. Centralpolicy-unintended out-of-pocket payments create policy implementation gaps which are discrepancies between policy as 'intent' and policy as 'practice. ${ }^{3} 3,64$ In a complex adaptive health system, policy as intent is not always policy as practised due to complex interactions between the actors, processes, content and the context of the policy. ${ }^{65,66}$ The gap between intended and experienced policy is further influenced by the power of frontline workers in their translation of policy into practise as described by Lehman and Gilson in South Africa. ${ }^{67}$

The rationale of this study is to understand this policy implementation gap hindering the attainment of UHC in LMICs of SSA, conscientize health system actors regarding the inequity created by this ignored implementation gap and call policy actors to action.

This study sought to synthesize the published evidence available on the 'what' and 'why' of central-policy-unintended out-of-pocket payments for services covered by health insurance schemes in SSA. Specifically, we asked: (1) What central-policy-unintended out-of-pocket payments are occurring for services under health insurance schemes? (2) Why are insured clients paying for services covered by the schemes?

In this paper, we briefly examine the theoretical concepts underpinning the study. We describe the methods used for this narrative synthesis review and synthesise our findings into a narrative based on broad themes from our starting theoretical concepts and inductive themes. We end by discussing the findings of this work.

\section{Theoretical Concepts}

The study drew on Lipsky's street level bureaucracy (SLB) theory, the concept of practical norms, and Taryn Vian's framework of corruption in the health system for conceptualization and analysis.

Street level bureaucrats are frontline workers of public sector agencies who have autonomy and use discretion in the award of sanctions or benefits to the public. They are effectively policy decision-makers whose actions and inactions become the face of policy as practised. Their actions and inactions can lead to policy as practised different from policy as stated for several reasons. Firstly, the nature of their work is such that it cannot be automated, discretion is unavoidable, and they have to interact extensively with the general public. Secondly, is their condition of work. They are sometimes faced with difficult choices because they do not have adequate amounts of the needed resources to perform. They may face ambiguous and contradictory expectations and demands from the higher authorities in their agencies. Street level bureaucrats thus have to develop some coping mechanisms to handle all these conflicts. These coping mechanisms may unavoidably and unintentionally affect the expression of the policy they are supposed to implement. These coping mechanisms are highly influenced by their independence in a bureaucratic establishment. The actions stemming from their independence are affected by their rationalisation, attitudes and the extensive discretionary power they wield. Policy becomes a bottom-up process. ${ }^{68}$

$\mathrm{Vian}^{52}$ in his review paper to describe how rationalisation, opportunities and pressures enable corruption in the health sector, proposed a "framework of corruption in the health sector" that solidifies some concepts and models of corruption propounded by previous scholars through an "organisational view." He defined corruption as that which "occurs when public officials who have been given the authority to carry out goals which further the public good, instead use their position and power to benefit themselves and others close to them."

From the perspective of the government official, corruption is stimulated by three main drivers: (1) The official's ability to justify his actions or rationalise his behaviour based on normative culture, individual attitudes and personality, (2) pressure from clients or financial constraints, and (3) Opportunity to abuse power. The opportunity to abuse power is influenced by monopoly, citizen voice, transparency, accountability, enforcement and discretion. ${ }^{52}$

In his study of corruption in West African states, de Sardan proposes that the gap between official rules and actual practice of the state and state agents is governed by informal rules that generate "practical norms." This gives an underlying meaning and some structure and system to what one might observe as mere random corruption on the surface. Practical norms are embedded in the routine practices of civil servants through 'the generalized exchange of favours,' 'clientelism,' 'culture of impunity,' 'arenas of suspicion,' 'privilegism' and contempt for anonymous users, among other norms. ${ }^{69,70}$

\section{Methods \\ Study Site}

Almost all countries in SSA have a history of colonisation that influences their current bureaucracies. Their health systems have evolved through post-colonial eras of "free healthcare" for all, structural adjustment, payment of user fees, user fees exemptions and currently the introduction of health insurance towards the attainment of UHC.

The region is characterised by great cultural diversity across and within countries, and high poverty rates despite a wealth of natural resources. More than half of the world's poor can be found in SSA. ${ }^{71}$ The region has a medium Human 
Development Index of 0.547 and has $43.2 \%$ of the world's multidimensionally poor. ${ }^{72}$ Table 1 gives a general context of the countries in which the reviewed studies were conducted.

\section{Study Design}

This study employed a narrative synthesis methodology because it is an appropriate approach when heterogenous literature types involving both qualitative and quantitative work are to be studied ${ }^{75,76}$ and is a good fit for handling diverse groups of studies, ${ }^{77}$ particularly when one seeks to synthesise qualitative evidence. ${ }^{78}$ 'Textual narrative synthesis' helped to draw new comprehensive conclusions, from empirical evidence through the use of text rather than data. ${ }^{76,77,79}$

\section{Information Sources}

Literature search was limited to English language literature identified from the International Development Research Centre (IDRC) online data base which provided access to an electronic collection catalogue. This made it possible to search the content of external databases simultaneously with EBSCO databases, using a single interface. EBSCO Databases searched included Academic Search Complete, Business Source Premier, CAB Abstracts, EconLit, LISTA MEDLINE, SocINDEX. Other databases, platforms and indexes that were searched via this platform included Cairn.info, Directory of Open Access Journals (DOAJ), ERIC, HeinOnline, JSTOROECD, iLibrary, Persée, SciELO, World Bank eLibrary, eBooks Collection, AGRICOLA, African Journals Online (AJOL), Eldis, Google Scholar, PubMed Central and SciDev. net.

\section{Search Terms}

An initial search in October 2018 for Ghana only, was later expanded to cover SSA. The initial search terms in October 2018 were: "Ghana National Health Insurance" AND "outof-pocket payment" AND "informal payment" OR "user fees" and "Ghana" AND "National Health Insurance." The expanded search to include countries in SSA ended on January 31, 2020. It included the search terms: "Africa AND informal fee* AND health insurance," "Africa AND informal payment* AND health insurance," "Africa AND informal charge* AND health insurance," "Africa AND user fee* AND health insurance," "Africa AND user charge* AND health insurance," "Africa AND unofficial payment* OR "unofficial fee* OR "unofficial Charge* AND health insurance," "Africa AND out-of-pocket AND health insurance," "co-pay* AND Africa," "Africa AND out-of-pocket* AND Insurance" and "Africa AND health insurance."

\section{Inclusion Criteria}

The search yielded publications dated 1873-2019. The included articles were English language, peer-reviewed journal articles, covering empirical studies in SSA that documented 'centralpolicy-unintended' out-of-pocket payments under health insurance schemes in the findings or results section.

\section{Exclusion Criteria}

Studies conducted outside SSA, grey literature, reviews and studies that did not address central-policy-unintended payments were excluded.

\section{Identified Materials}

The initial literature search yielded, 1663 publications out of which 666 were peer-reviewed academic journal articles. After removing duplications, reviewing the titles and skimming the abstracts, 19 articles were identified for full text screening. Nine articles were selected based on the inclusion criteria. Review of relevant references yielded one additional article. The final expanded search to include all of SSA identified eight additional articles, making a total of eighteen articles. Figure summarizes the literature search and selection.

The included articles (Table 2) comprised five mixed methods studies, ${ }^{62,80-83}$ five qualitative studies, ${ }^{60,84-87}$ seven cross-sectional surveys ${ }^{88-94}$ and one quasi-experimental study, ${ }^{95}$ spanning the period 2011-2019.

\section{Quality Criteria}

The quality of the articles selected was evaluated based on (1)

Table 1. Context of the Countries in Which the Reviewed Studies Were Conducted

\begin{tabular}{|c|c|c|c|c|c|c|}
\hline \multirow{2}{*}{ Indicator } & \multicolumn{6}{|c|}{ Country } \\
\hline & Burkina Faso & Cote d'Ivoire & Ghana & Kenya & South Africa & Tanzania \\
\hline Total population in thousands (2016) & 18646 & 23696 & 28207 & 48462 & 56015 & 55572 \\
\hline UHC index of essential service coverage & 40 & 47 & 47 & 55 & 69 & 43 \\
\hline Life expectancy at birth/years & 61.6 & 57.8 & 64.1 & 66.7 & 64.1 & 65.5 \\
\hline Population in multidimensional poverty, headcount/\% & 83.8 & 46.1 & 30.1 & 38.7 & 6.3 & 55.4 \\
\hline Human development index & 0.452 & 0.538 & 0.611 & 0.601 & 0.709 & 0.529 \\
\hline Gender inequality index & 0.594 & 0.638 & 0.538 & 0.518 & 0.406 & 0.556 \\
\hline Skilled labour force (\% of labour force) & 5.0 & 25.5 & 28.5 & 40.5 & 52.2 & 5.0 \\
\hline Out-of-pocket expenditure as \% of total expenditure on health (2014) & 39.09 & 50.81 & 26.84 & 26.11 & 6.49 & 23.21 \\
\hline Total expenditure on health as \% of GDP (2014) & 5.0 & 5.7 & 3.6 & 5.7 & 8.8 & 5.6 \\
\hline Maternal mortality rate (per 100000 live births, 2017) & 320 & 617 & 308 & 342 & 119 & 524 \\
\hline
\end{tabular}

Abbreviations: GDP, gross domestic product; UHC, universal health coverage.

Sources: The Global Health Observatory (World Health Organization) ${ }^{73}$ and 2020 Human Development Report (United Nations Development Programme). ${ }^{74}$ 


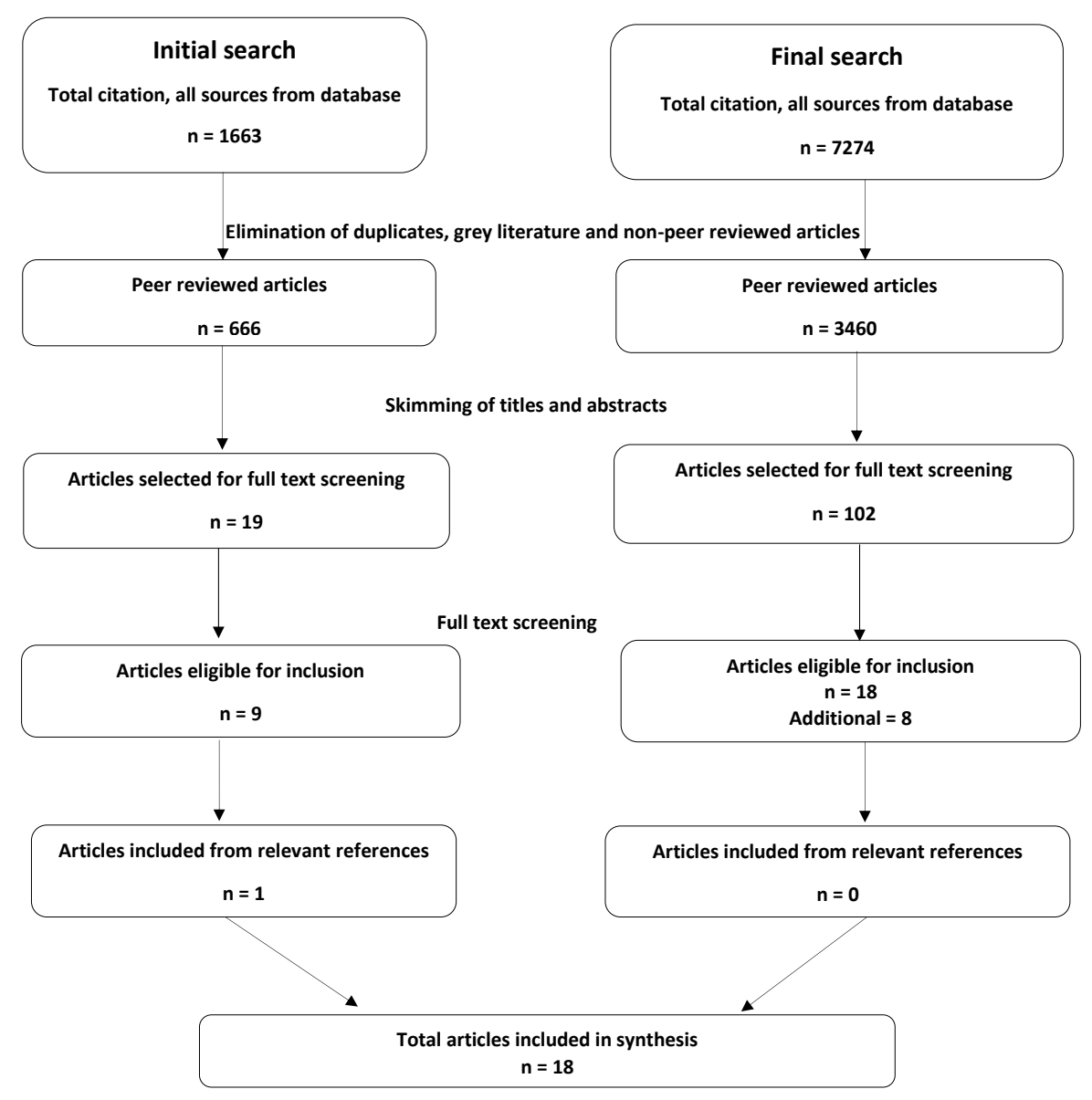

Figure. Flowchart of Article Selection Process.

the use of theory, concepts or frameworks, (2) triangulation, (3) proper documentation of the study process and systematic presentation of data, (4) clear contextualisation of the research, (5) the quality of the empirical evidence presented in the paper, (6) discussion of limitations, (7) ethical considerations and (8) reflexivity. ${ }^{97-99}$ Additional criteria for quantitative studies were, (9) the use of appropriate sampling technique and (10) sample size calculation. Each criterion carried a maximum mark of 1 . The papers were assessed based on scores as: Excellent (10), very good (above 7); good (6-7); fairly good (5); poor (below 5). All the included studies scored 6 and above (Supplementary file 1).

\section{Data Analysis}

The principal researcher, a Fellowship student, carried out the literature search, article selection and data extraction process with guidance and supervision from the other researchers who were her fellowship dissertation supervisors. The theoretical concepts, inclusion, exclusion and quality criteria were discussed and agreed upon by all authors before the research process. The second author cross-validated the data extraction and analysis process.

A data extraction sheet (see Box 1) was used to extract data from the eighteen articles individually. An Excel spreadsheet was then developed to organise the extracted data into a matrix to help analyse the data within and across papers. The extracted data was deductively and inductively analysed into sub-themes and themes drawing on the theoretical concepts of corruption, practical norms and SLB taking note of new, emerging themes from the data. Data was extracted from findings; raw data, summarized text, cited text, context and/ or arguments in an iterative way. ${ }^{100}$

The synthesis entailed identification of constructs, findings, relationships between findings and setting limits for the synthesis. ${ }^{75,101}$

A preliminary presentation of the protocol and initial findings was made at the Faculty of Public Health preconference workshop of the Ghana College of Physicians and Surgeons during the December 2018 Annual General Scientific Meeting for peer-review before finalizing the protocol and approach.

\section{Results}

The studies included in the synthesis covered six different countries in SSA with majority from Ghana (Table 2). The findings are presented below organized by the two research questions.

What Central-Policy-Unintended Payments Are Occurring We classified the types of services that insured clients made central-policy-unintended out-of-pocket payments for into: medicines, ${ }^{60,62,88-93,80-87}$ diagnostic tests, ${ }^{62,80,81,85,88-93}$ in-patient services, ${ }^{60,62,80,84,89,90,92,94}$ out-patient services, ${ }^{60,62,88-90,94,95}$ blood transfusion services, ${ }^{62,80}$ antenatal, ${ }^{62,80,88}$ labour and delivery services ${ }^{62,81,83,87,88}$ and others (Table 3 ). Other services included surgeries, ${ }^{88}$ supplies for deliveries ${ }^{62,80,81,87,89}$ and non-specified 
Table 2. Summary of Selected Articles for the Review Process

\begin{tabular}{|c|c|c|c|c|c|c|}
\hline Author(s), Title and Year of Publication & $\begin{array}{l}\text { Country of } \\
\text { Study }\end{array}$ & Aim (s) of Study & Study Population & $\begin{array}{l}\text { Methodology (Study Design } \\
\text { and Analysis) }\end{array}$ & $\begin{array}{l}\text { Framework, Concept, or } \\
\text { Theory }\end{array}$ & $\begin{array}{l}\text { Type of Health Insurance } \\
\text { Scheme }\end{array}$ \\
\hline $\begin{array}{l}\text { Agyepong et al, } 2016 \\
\text { The "Universal" in UHC and Ghana's National Health } \\
\text { Insurance Scheme: policy and implementation } \\
\text { challenges and dilemmas of a lower middle-income } \\
\text { country }\end{array}$ & Ghana & $\begin{array}{l}\text { Explores NHIS enrolment barriers } \\
\text { and facilitators. Provides insights and } \\
\text { lessons for attainment of UHC }\end{array}$ & $\begin{array}{l}\text { Adult groups of } \\
\text { currently enrolled, } \\
\text { previously enrolled, } \\
\text { currently uninsured, } \\
\text { never insured }\end{array}$ & $\begin{array}{l}\text { Exploratory case study } \\
\text { design. Mixed methods. } \\
\text { Purposive sampling. } \\
\text { Descriptive statistics and } \\
\text { thematic analysis }\end{array}$ & $\begin{array}{l}\text { SLB theory. } \\
\text { Framework of results } \\
\text { developed. Preliminary theory } \\
\text { used }\end{array}$ & $\begin{array}{l}\text { Social health insurance } \\
\text { (NHIS) }\end{array}$ \\
\hline $\begin{array}{l}\text { Aidam et al, } 2016 \\
\text { The effect of health insurance on out-of-pocket } \\
\text { payments, catastrophic expenditures and healthcare } \\
\text { utilization in Ghana: case of Ga South Municipality }\end{array}$ & Ghana & $\begin{array}{l}\text { Determines the impact of NHIS } \\
\text { membership on healthcare utilization } \\
\text { and CHE }\end{array}$ & Households & $\begin{array}{l}\text { Cross-sectional survey. } \\
\text { Purposive sampling }\end{array}$ & $\begin{array}{l}\text { Statistical concepts/models } \\
\text { used. Hypothesis testing }\end{array}$ & $\begin{array}{l}\text { Social health insurance } \\
\text { (NHIS) }\end{array}$ \\
\hline $\begin{array}{l}\text { Aryeetey et al, } 2016 \\
\text { Can health insurance protect against out-of-pocket } \\
\text { catastrophic expenditures and also support poverty } \\
\text { reduction? Evidence from Ghana's National Health } \\
\text { Insurance Scheme }\end{array}$ & Ghana & $\begin{array}{l}\text { Determines the effect of out-of-pocket } \\
\text { expenditure on poverty and the effect } \\
\text { of health insurance on out-of-pocket } \\
\text { expenditure, catastrophic expenditure } \\
\text { and poverty }\end{array}$ & Households & $\begin{array}{l}\text { Cross-sectional survey } \\
\text { with follow up survey in } 2 \\
\text { years. Three stage sampling } \\
\text { procedure }\end{array}$ & $\begin{array}{l}\text { Methodology developed by } \\
\text { O'Donnell et al. Pen's parade. } \\
\text { Random effects model. Probit } \\
\text { model. Durbin-Wu-Hausman } \\
\text { endogeneity test }\end{array}$ & $\begin{array}{l}\text { Social health insurance } \\
\text { (NHIS) }\end{array}$ \\
\hline $\begin{array}{l}\text { Ashigbie et al, } 2016 \\
\text { Challenges of medicines management in the public and } \\
\text { private sector under Ghana's National Health Insurance } \\
\text { Scheme - A qualitative study }\end{array}$ & Ghana & $\begin{array}{l}\text { Explores public and private care } \\
\text { providers' perception of the challenges } \\
\text { and consequences associated with the } \\
\text { NHIS' medicines management policies } \\
\text { and practices in Ghana }\end{array}$ & $\begin{array}{l}\text { Private, public } \\
\text { and mission } \\
\text { pharmaceutical } \\
\text { providers }\end{array}$ & $\begin{array}{l}\text { Qualitative study. Purposive } \\
\text { sampling. Thematic analysis }\end{array}$ & $\begin{array}{l}\text { Faden et al's concept on } \\
\text { Insurance System Medicines } \\
\text { Strategies, }{ }^{96} \text { Ghana's Medicines } \\
\text { management policy }\end{array}$ & $\begin{array}{l}\text { Social health insurance } \\
\text { (NHIS) }\end{array}$ \\
\hline $\begin{array}{l}\text { Attia-Konan et al, } 2019 \\
\text { Distribution of out-of-Pocket expenditures in a sub- } \\
\text { Saharan African country: evidence from the national } \\
\text { survey of household standard of living, Cote d'Ivoire }\end{array}$ & $\begin{array}{l}\text { Cote } \\
\text { d'Ivoire }\end{array}$ & $\begin{array}{l}\text { Estimates the direct payments made to } \\
\text { take care of health expenditures and } \\
\text { their distribution according to different } \\
\text { areas of residence }\end{array}$ & Households & $\begin{array}{l}\text { Cross-sectional survey. } \\
\text { Stratified random sampling }\end{array}$ & $\begin{array}{l}\text { Anderson's conceptual } \\
\text { framework on factors } \\
\text { determining healthcare } \\
\text { demand }\end{array}$ & $\begin{array}{l}\text { Voluntary social health } \\
\text { insurance (private health } \\
\text { insurance) }\end{array}$ \\
\hline $\begin{array}{l}\text { Beogo et al, } 2016 \\
\text { Out-of-pocket expenditure and its determinants in } \\
\text { the context of private healthcare sector expansion in } \\
\text { SSA urban cities: evidence from household survey in } \\
\text { Ouagadougou, Burkina Faso }\end{array}$ & $\begin{array}{l}\text { Burkina } \\
\text { Faso }\end{array}$ & $\begin{array}{l}\text { Investigates: }(a) \text { the level of out-of- } \\
\text { pocket expenditure on healthcare, } \\
(b) \text { the distribution of out-of-pocket } \\
\text { expenditure based on its primary } \\
\text { components and on the ownership } \\
\text { of healthcare facilities, and }(c) \text { the } \\
\text { proximate determinants of out-of- } \\
\text { pocket expenditure }\end{array}$ & Households & $\begin{array}{l}\text { Cross-sectional survey. } \\
\text { Two-staged cluster random } \\
\text { sampling }\end{array}$ & None & $\begin{array}{l}\text { Voluntary social health } \\
\text { insurance (private health } \\
\text { insurance) }\end{array}$ \\
\hline $\begin{array}{l}\text { Dalaba et al, } 2014 \\
\text { Does the national health insurance scheme in Ghana } \\
\text { reduce household cost of treating malaria in the } \\
\text { Kassena-Nankana districts? }\end{array}$ & Ghana & $\begin{array}{l}\text { Assesses the impact of NHIS in } \\
\text { decreasing malaria treatment cost for } \\
\text { households in Kassena-Nankana }\end{array}$ & Households & $\begin{array}{l}\text { Cross-sectional household } \\
\text { survey. Random sampling. } \\
\text { Principal component } \\
\text { analysis technique }\end{array}$ & None & $\begin{array}{l}\text { Social health insurance } \\
\text { (NHIS) }\end{array}$ \\
\hline
\end{tabular}


Table 2. Continued

\begin{tabular}{|c|c|c|c|c|c|c|}
\hline Author(s), Title and Year of Publication & $\begin{array}{l}\text { Country of } \\
\text { Study }\end{array}$ & Aim (s) of Study & Study Population & $\begin{array}{l}\text { Methodology (Study Design } \\
\text { and Analysis) }\end{array}$ & $\begin{array}{l}\text { Framework, Concept, or } \\
\text { Theory }\end{array}$ & $\begin{array}{l}\text { Type of Health Insurance } \\
\text { Scheme }\end{array}$ \\
\hline $\begin{array}{l}\text { Dalinjong et al, } 2017 \\
\text { The operations of the free maternal care policy and out } \\
\text { of pocket payments during childbirth in rural Northern } \\
\text { Ghana }\end{array}$ & Ghana & $\begin{array}{l}\text { Evaluates out of pocket payment and } \\
\text { the impact on women during childbirth } \\
\text { under the free maternal care policy of } \\
\text { the NHIS in poor rural Northern Ghana }\end{array}$ & $\begin{array}{l}\text { Women who gave } \\
\text { birth in Health } \\
\text { facilities }\end{array}$ & $\begin{array}{l}\text { Convergent parallel mixed } \\
\text { methods approach. } \\
\text { Purposive sampling. } \\
\text { Thematic approach }\end{array}$ & None & $\begin{array}{l}\text { Social health insurance } \\
\text { (NHIS) }\end{array}$ \\
\hline $\begin{array}{l}\text { Dalinjong et al, }{ }^{a} 2018 \\
\text { The implementation of the free maternal health policy } \\
\text { in rural Northern Ghana: synthesised results and lessons } \\
\text { learnt }\end{array}$ & Ghana & $\begin{array}{l}\text { Explores the facilitators, barriers to } \\
\text { health access under the free maternal } \\
\text { health policy of the NHIS and the } \\
\text { implications }\end{array}$ & $\begin{array}{l}\text { Women who had } \\
\text { given birth in health } \\
\text { facilities }\end{array}$ & $\begin{array}{l}\text { Convergent parallel mixed } \\
\text { methods approach. } \\
\text { Purposive sampling. } \\
\text { Thematic analysis }\end{array}$ & $\begin{array}{l}\text { Synthesis of study results into } \\
\text { a framework }\end{array}$ & $\begin{array}{l}\text { Social health insurance } \\
\text { (NHIS) }\end{array}$ \\
\hline $\begin{array}{l}\text { Dalinjong et al, } 2018 \\
\text { Has the free maternal health policy eliminated out of } \\
\text { pocket payments for maternal health services? Views } \\
\text { of women, health providers and insurance managers in } \\
\text { Northern Ghana }\end{array}$ & Ghana & $\begin{array}{l}\text { Explores perceptions of cost, actual } \\
\text { payment and source of funds for } \\
\text { services under the NHIS's free maternal } \\
\text { care policy }\end{array}$ & $\begin{array}{l}\text { Women who used } \\
\text { maternal health } \\
\text { services in health } \\
\text { facilities }\end{array}$ & $\begin{array}{l}\text { Convergent parallel mixed } \\
\text { methods approach. } \\
\text { Purposive sampling. } \\
\text { Thematic analysis }\end{array}$ & None & $\begin{array}{l}\text { Social health insurance } \\
\text { (NHIS) }\end{array}$ \\
\hline $\begin{array}{l}\text { Kabia et al, } 2019 \\
\text { "We are called the et cetera": experience of the poor } \\
\text { with health financing reforms that target them in Kenya }\end{array}$ & Kenya & $\begin{array}{l}\text { To examine the experiences of the } \\
\text { poor with health financing reforms and } \\
\text { challenges they encounter in accessing } \\
\text { their benefits under these reforms in } \\
\text { Kenya }\end{array}$ & $\begin{array}{l}\text { Poor people and } \\
\text { people in the } \\
\text { lowest quintile }\end{array}$ & $\begin{array}{l}\text { Qualitative cross-sectional } \\
\text { study. Purposive sampling }\end{array}$ & $\begin{array}{l}\text { conceptual framework } \\
\text { adapted from Jacob et al }\end{array}$ & $\begin{array}{l}\text { Social Health Insurance. } \\
\text { [Health Insurance Subsidy } \\
\text { Program under National } \\
\text { Health Insurance Fund] }\end{array}$ \\
\hline $\begin{array}{l}\text { Kusi et al, } 2015 \\
\text { Does the National Health Insurance Scheme provide } \\
\text { financial protection to households in Ghana? }\end{array}$ & Ghana & $\begin{array}{l}\text { Determines the effect of NHIS on } \\
\text { out-of-pocket health expenditure and } \\
\text { CHE for households through a cross- } \\
\text { sectional survey in three districts } \\
\text { across Ghana }\end{array}$ & Households & $\begin{array}{l}\text { Cross-sectional household } \\
\text { survey. } \\
\text { Systematic sampling }\end{array}$ & $\begin{array}{l}\text { Hypothesis testing. } \\
\text { Methodology by O'Donnell } \\
\text { et al }\end{array}$ & $\begin{array}{l}\text { Social health insurance } \\
\text { (NHIS) }\end{array}$ \\
\hline $\begin{array}{l}\text { Macha et al, } 2012 \\
\text { Factors influencing the burden of healthcare benefits in } \\
\text { Ghana, Tanzania and South Africa }\end{array}$ & $\begin{array}{l}\text { Ghana, } \\
\text { Tanzania, } \\
\text { South } \\
\text { Africa }\end{array}$ & $\begin{array}{l}\text { Explores factors that influence } \\
\text { distribution of healthcare benefits } \\
\text { focusing on regressive financing } \\
\text { mechanisms and the reasons for pro- } \\
\text { rich distribution of benefits in terms } \\
\text { of affordability, acceptability and } \\
\text { accessibility in Ghana, Tanzania and } \\
\text { South Africa }\end{array}$ & Scheme members & $\begin{array}{l}\text { Mixed methods approach. } \\
\text { Purposive sampling and } \\
\text { 2-staged stratified random } \\
\text { sampling }\end{array}$ & Access framework & $\begin{array}{l}\text { Voluntary social health } \\
\text { insurance (private health } \\
\text { insurance), compulsory } \\
\text { social health insurance } \\
\text { (National Health } \\
\text { Insurance Fund, NHIS, } \\
\text { community health fund, } \\
\text { Tiba Kwa Kadi) }\end{array}$ \\
\hline
\end{tabular}




\section{Derkyi-Kwarteng et al}

Table 2. Continued

\begin{tabular}{|c|c|c|c|c|c|c|}
\hline Author(s), Title and Year of Publication & $\begin{array}{l}\text { Country of } \\
\text { Study }\end{array}$ & Aim (s) of Study & Study Population & $\begin{array}{l}\text { Methodology (Study Design } \\
\text { and Analysis) }\end{array}$ & $\begin{array}{l}\text { Framework, Concept, or } \\
\text { Theory }\end{array}$ & $\begin{array}{l}\text { Type of Health Insurance } \\
\text { Scheme }\end{array}$ \\
\hline $\begin{array}{l}\text { Mpanza et al, } 2019 \\
\text { Reasons why insured consumers co-pay for medicines at } \\
\text { retail pharmacies in Pretoria, South Africa }\end{array}$ & $\begin{array}{l}\text { South } \\
\text { Africa }\end{array}$ & $\begin{array}{l}\text { Explores views about co-payments and } \\
\text { factors that influence Pretoria medical } \\
\text { scheme members' co-payments when } \\
\text { purchasing prescription medicines at } \\
\text { pharmacies, despite insurance status }\end{array}$ & Scheme members & $\begin{array}{l}\text { Exploratory qualitative } \\
\text { study. Purposive sampling }\end{array}$ & None & $\begin{array}{l}\text { Voluntary social insurance } \\
\text { (private health insurance) }\end{array}$ \\
\hline $\begin{array}{l}\text { Nguyen et al, } 2011 \\
\text { The financial protection effect of Ghana National Health } \\
\text { Insurance Scheme: evidence from a study in two rural } \\
\text { districts }\end{array}$ & Ghana & $\begin{array}{l}\text { Evaluates the impact of NHIS on out- } \\
\text { of-pocket expenditure by households } \\
\text { and CHE }\end{array}$ & Households & $\begin{array}{l}\text { Cross-sectional household } \\
\text { survey. } \\
\text { Two-stage cluster random } \\
\text { sampling }\end{array}$ & $\begin{array}{l}\text { Wagstaff and van Door-slater } \\
\text { concept of } \mathrm{CHE}\end{array}$ & $\begin{array}{l}\text { Social health insurance } \\
\text { (NHIS) }\end{array}$ \\
\hline $\begin{array}{l}\text { Siita et al, } 2019 \\
\text { Does capitation affect patient satisfaction and } \\
\text { prevalence of out-of-pocket payments in the insured? A } \\
\text { propensity score analysis of Ghana's demographic and } \\
\text { health survey data }\end{array}$ & Ghana & $\begin{array}{l}\text { Examines the effects of capitation on } \\
\text { perceived health service quality and } \\
\text { prevalence of out-of-pocket health } \\
\text { payments using Ghana's capitation } \\
\text { pilot as a case study }\end{array}$ & Scheme members & $\begin{array}{l}\text { Quasi-experimental study. } \\
\text { Stratified random sampling. } \\
\text { Principal component } \\
\text { analysis for robustness } \\
\text { Rosenbaum - bounds } \\
\text { sensitivity analysis }\end{array}$ & $\begin{array}{l}\text { Principal component analysis, } \\
\text { Rosenbaum - bounds } \\
\text { sensitivity analysis }\end{array}$ & $\begin{array}{l}\text { Social health insurance } \\
\text { (NHIS) }\end{array}$ \\
\hline $\begin{array}{l}\text { Suchman, } 2018 \\
\text { Accrediting private providers with National Health } \\
\text { Insurance to better serve low-income populations in } \\
\text { Kenya and Ghana: a qualitative study }\end{array}$ & $\begin{array}{l}\text { Ghana and } \\
\text { Kenya }\end{array}$ & $\begin{array}{l}\text { Studies the effect of participation in a } \\
\text { SHI scheme on private providers' ability } \\
\text { to serve poorer patient populations } \\
\text { with quality health services }\end{array}$ & Poor people & $\begin{array}{l}\text { Qualitative study. Purposive } \\
\text { sampling }\end{array}$ & None & $\begin{array}{l}\text { Social health insurance } \\
\text { (NHIS, National Health } \\
\text { Insurance Fund) }\end{array}$ \\
\hline $\begin{array}{l}\text { Witter et al, } 2013 \\
\text { An exploratory study of the policy process and early } \\
\text { implementation of the free NHIS coverage for pregnant } \\
\text { women in Ghana }\end{array}$ & Ghana & $\begin{array}{l}\text { Explores the policy development } \\
\text { process and early implementation } \\
\text { of the free NHIS policy for pregnant } \\
\text { women in Ghana }\end{array}$ & $\begin{array}{l}\text { Pregnant women } \\
\text { and newborns }\end{array}$ & $\begin{array}{l}\text { Qualitative study. Purposive } \\
\text { sampling }\end{array}$ & Thematic framework & $\begin{array}{l}\text { Social health insurance } \\
\text { (NHIS) }\end{array}$ \\
\hline
\end{tabular}

Abbreviations: NHIS, National Health Insurance Scheme; UHC, universal health coverage; SLB, street level bureaucracy; CHE, catastrophic health expenditure; SHI, social health insurance.

a Used to differentiate the 2018 papers by same author. 


\section{Box 1. Data Extraction Template For Included Articles}

Title

Author

Year

Country

Study site

Aim of the study

Type of health insurance

Population under study

\section{What out-of-pocket payments are occurring? \\ - Timing: Initial/post \\ - Receipted/not receipted/unknown \\ - Mode of payment: Cash/kind/favour/gift \\ - Facility type \\ - Facility-based/outside the facility \\ - $\quad$ Type of service: (eg, medicine, laboratory, ultrasound) \\ - Cadre of health worker involved \\ - Initiator of the payment: Health worker/patient}

Why are the out-of-pocket payments occurring?
(factors influencing the out-of-pocket payment)
- $\quad$ Personal
- $\quad$ Organisational
- $\quad$ Policy factors
- Socio-cultural factors
- Other contextual factors
- Other
Quality Criteria
- (see Supplementary file 1 for details)
Comments

services. ${ }^{82,83,85,88}$

We classified central-policy-unintended payments into 'peripheral-policy-intended' and 'peripheral-policyunintended.' The papers were not always explicit and peripheral-policy-intended payments were inferred from instances where payments appeared to be facility-based ${ }^{62,84,85}$ or from phrases such as "double-billing," "balance-billing," "top-ups," "user fees" "referred to the cashier" and "copays." ${ }^{2,83,85-87}$ Payments made upon referral were considered peripheral-policy-intended payments since there was no evidence to the contrary. Most referrals were for medicines and insured clients paid more for prescribed medicines than the non-insured, particularly under private insurance schemes. ${ }^{86,88,92,93}$ There was no evidence suggesting that these referrals were a form of rent seeking. Seven of the papers mentioned peripheral-policy-intended payments in the facility and ten of the papers mentioned peripheral-policyintended payments on referral.

Peripheral-policy-unintended payments were made in cash (7 studies) and kind (5 studies). These payments were described in the papers by words such as 'informal,' 'unofficial,' 'unauthorised,' 'demands,' 'bribes' and "outright under the table charges and extortion." ${ }^{60,83-85,88,91,94}$ Peripheralpolicy-unintended payments in kind were mainly made by pregnant women. They comprised soap, disinfectants and other supplies (rubber mackintosh, sanitary pad) used during labour and delivery. ${ }^{62,80,81,83,87}$ Eleven papers were not specific as to whether the payments were in cash or in kind. The types of peripheral-policy-unintended payments made that could be clearly classified under corrupt practices governed by practical norms ${ }^{102}$ were described as levies (6 papers), gratuity, commission, unwarranted fees and misappropriation (4 papers).

In more than half of the studies reviewed, information was inadequate and some cash payments could not be conclusively categorised as 'peripheral-policy-intended' or 'peripheralpolicy-unintended.' ${ }^{60,62,95,80-82,87,89,90,92,93}$

'Timing' of the payments (eg, 'before,' 'during' or 'after' service provision) was not significant in determining the type of payment. All payments in private facilities, generally appeared to be higher than in public facilities. ${ }^{60,85}$ Apart from midwives ${ }^{60,83,87}$ and pharmacy or dispensary staff, ${ }^{82,86}$ no other cadre of health workers was specifically mentioned as initiators or recipients of payments in any of the selected articles. Generally, the central-policy-unintended payments appeared to be potentially regressive with clients in low socioeconomic groups most affected. ${ }^{62,82,86}$

Why Are the Central-Policy-Unintended Payments Occurring Our analysis suggests that the reasons for central-policyunintended payments can be explained by our starting theories of SLB, Vian's theory of corruption, Olivier de Sardan's concept of practical norms, scheme design and context.

\section{Context and Design}

The countries involved in this review were at various stages of health system financing reforms under the name of health insurance, but with variations in approach (Table 2). In South Africa, Burkina Faso and Cote d'Ivoire health insurance was voluntary private health insurance, mainly for high income earners sometimes managed by for-profit companies. Tanzania and Kenya had a more social health insurance type scheme in the form of their compulsory National Health Fund for formal sector employees. Tanzania additionally had voluntary social health insurance in rural areas through the community health fund and in urban areas, through the Tiba Kwa Kadi. Ghana's National Health Insurance Scheme (NHIS) was universal in intent but had challenges with enforcing compulsory enrolment for the informal sector given the outof-pocket contributory premiums required additionally to the general tax funding. ${ }^{83}$ Kenya was working on scaling up its National Health Fund to include the informal sector. ${ }^{60,83,85}$ The insurance schemes in Ghana, Tanzania and Kenya had exemptions and waivers for vulnerable groups. ${ }^{62,82,83,85}$ Generally, the poor and lower-income groups in the informal sectors had limited health insurance coverage due to the barrier posed by out-of-pocket premiums and opportunity costs in some cases. ${ }^{82,83}$ All the countries were anticipating the introduction or scale up of a compulsory social national health insurance type scheme towards the attainment of UHC. The health systems and policy issues leading to centralpolicy-unintended payments identified in the review papers are depicted in Table 4. 
Table 3. Summary of "What" Services Insurance Clients Paid for Out-of-Pocket

\begin{tabular}{|c|c|c|c|c|c|c|c|c|}
\hline Reference & Medicines & $\begin{array}{l}\text { In-Patient } \\
\text { Services }\end{array}$ & $\begin{array}{l}\text { Out-Patient } \\
\text { Services }\end{array}$ & Blood Transfusion & Diagnostic Tests & $\begin{array}{l}\text { Labour And } \\
\text { Delivery }\end{array}$ & $\begin{array}{l}\text { Antenatal } \\
\text { Service }\end{array}$ & Other \\
\hline Agyepong et al, 2016 & $\checkmark$ & & & & & $\checkmark$ & & $\checkmark$ \\
\hline Aidam et al, 2016 & V & & & & V & & & \\
\hline Aryeetey et al, 2016 & & v & $v$ & & & & & \\
\hline Ashigbie et al, 2016 & $v$ & $v$ & & & & & & \\
\hline Attia-Konan et al, 2019 & v & $\checkmark$ & & & v & & & \\
\hline Beogo et al, 2016 & V & & & & v & & & \\
\hline Dalaba et al, 2014 & $v$ & $v$ & $v$ & & $\checkmark$ & & & \\
\hline Dalinjong et al, 2017 & v & $v$ & & $v$ & v & v & $v$ & $v$ \\
\hline Dalinjong et al, ${ }^{\text {a }} 2018$ & V & & & & v & v & & v \\
\hline Dalinjong et al, 2018 & $v$ & $v$ & $v$ & v & $v$ & v & $v$ & $v$ \\
\hline Kabia et al, 2019 & $\checkmark$ & & & & v & & & $\checkmark$ \\
\hline Kusi et al, 2015 & V & V & V & & V & & & \\
\hline Macha et al, 2012 & v & & & & & & & v \\
\hline Mpanza et al, 2019 & $v$ & & & & & & & \\
\hline Nguyen et al, 2011 & V & & 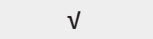 & & V & V & $\sqrt{ }$ & V \\
\hline Siita et al, 2019 & & & $v$ & & & & & \\
\hline Suchman, 2018 & $\checkmark$ & v & $\checkmark$ & & & & & $\checkmark$ \\
\hline Witter et al, 2013 & $v$ & & & & & $v$ & & $v$ \\
\hline $\begin{array}{l}\text { Total number of articles } \\
\text { with type of service }\end{array}$ & 16 & 8 & 7 & 2 & 10 & 6 & 3 & 9 \\
\hline
\end{tabular}

a Used to differentiate the 2018 papers by same author.

The purely private insurance scheme members mainly used private health facilities to deliver benefits while the other types of health insurance schemes used mainly public health facilities but also some accredited private health facilities. All public health facilities (including quasi-government) were accredited by default while private-for-profit facilities had to undergo a complex accreditation process. ${ }^{60}$ Accreditation for private pharmacies on the other hand was perceived to be easy and efficient. Contrary to public providers, private providers could easily renounce their accreditation status on account of delayed reimbursement, unfair adjustments in claims or low reimbursement rates. ${ }^{84}$ Health facilities were allocated reimbursement restrictions for services based on their level of accreditation such as, a clinic, maternity home, or a hospital, which sometimes limited the service they could provide to insured clients. Facilities were not reimbursed if they provided services above their accredited level of care. ${ }^{60,83,84,87}$ Health insurance reforms were not usually accompanied by the provision of infrastructure and other resources to meet the demand for service. Health insurance clients had to contend with poor road networks, ${ }^{83}$ and challenges in obtaining transportation to accredited facilities or facilities where they could get all needed services. In this regard, the poor and residents in rural areas had more limited access to healthcare than urban dwellers. ${ }^{62,81,82,84,85,87,91}$

Economically, there was generally a lack of funds for the schemes to operate from the macro-level to the micro-level of the health systems in Ghana, Tanzania and Kenya. In South Africa this was a problem between the schemes at the mesolevel and the micro-facility level causing clients to co-pay for medicines. ${ }^{86}$ This however did not come out strongly under private health insurance in the two francophone countries.
The lack of funds led to delays in reimbursement to health facilities lasting between 3-9 months, ${ }^{60,83-85,87}$ non-review of service tariffs by insurance schemes and low reimbursement rates. Health facilities became less credit worthy and had to deal with suppliers who refused to participate in tenders, leading to high operating costs. ${ }^{84}$ Insurance officials in Ghana also complained of lack of funds at district offices. ${ }^{83}$

Policy processes were sometimes not carefully thought through, documented and disseminated for implementation. In Ghana, the promise of foreign aid, the millennium development goals and interest of powerful national level actors affected the hasty agenda-setting, formulation and implementation of NHIS' "free" maternal care policy. Major stakeholders felt they had not been informed of policy details and that the policy content was not well-disseminated. Key stakeholders involved in the policy process were pacesetters in creating implementation gaps by charging central-policy-unintended out-of-pocket fees. There was no prior financial planning or budgeting and actors were not sure of the sustainability of "free" services with no clear documented sources of revenue. ${ }^{87}$ Providers and insurance officials generally considered the claims processing and vetting activities to be quite laborious and cumbersome since most facilities did not have electronic health information management systems. ${ }^{83,87}$ Policy regulation processes were either absent or poorly implemented..$^{60,83-87,93}$

There was a general sense of mistrust between various actors in the health system because actors were generally not transparent and accountable to each other. Private insurance scheme members and regulators thought that schemes took advantage of members' "reliance-on-scheme" and preferred to sponsor other interests rather than invest 
Table 4. Elements of SLB and Health Policy and Systems Issues Identified in Articles

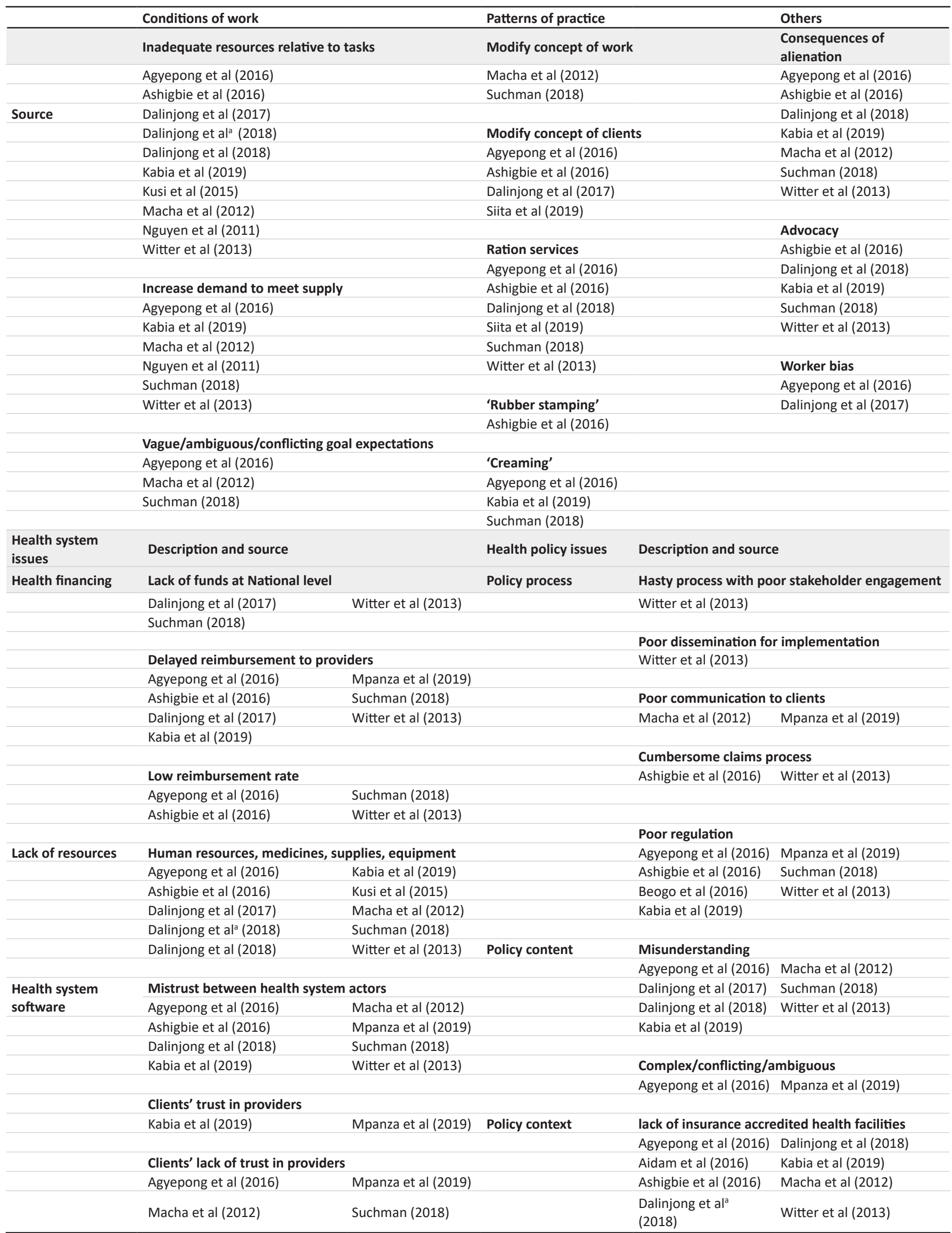

Abbreviation: SLB, street level bureaucracy

a Used to differentiate the 2018 papers by same author. 
in members' benefits. ${ }^{86}$ Clients in Tanzania also distrusted the management of the community health fund. ${ }^{82}$ The insurance clients and health workers in Ghana felt they had been deceived by government and that health insurance did not serve the purpose for which it was introduced. ${ }^{62,83,84}$ Insurance beneficiaries in Kenya felt "deceived" and "tricked" by the government when they had to make out-of-pocket payments in health facilities. ${ }^{85}$ In Ghana, Tanzania and Kenya people would not enrol or use health insurance even when enrolled because they still paid for services covered by the scheme..$^{60,82,83,85}$ Insurance schemes did not trust the claims submitted by service providers. They suspected that the claims were inflated, ${ }^{60,83,86}$ fraudulent ${ }^{60,84,87}$ or that providers were double-billing the clients and the scheme. ${ }^{60,87}$ They denied claims and adjusted payments with minimal explanations apparently based on these suspicions. ${ }^{84}$ Clients and providers in Ghana distrusted insurance officials because they sometimes collected informal charges from clients and private providers to speed up registration and accreditation processes. ${ }^{60,83,84}$

Clients generally trusted they got expensive but better quality and more responsive care from private than public facilities. Clients trusted the care they received based on the expertise of the attending provider. Thus health workers in lower-level public facilities were perceived to be inexperienced and unskilled. ${ }^{60,82,83,85}$ Some clients on the other hand trusted the health workers in the public health facilities because they were more knowledgeable and skilled. ${ }^{85}$ Due to the fear of misdiagnosis, and the apparent financial freedom offered by health insurance, clients usually "shopped" with the same complaint. ${ }^{84,87}$ Providers in Ghana perceived this as a moral hazard and suspected clients gave their medication to uninsured relatives or sold them for personal gain. ${ }^{84}$ The higher level public facilities were also preferred because they offered a wider range of services. ${ }^{60}$ Doctors and pharmacists used their power to influence clients to co-pay for expensive medicines in South Africa based on trust in their expertise. ${ }^{86}$ Similarly, private insurance clients in Cote d'Ivoire and Burkina Faso who consulted with doctors made more outof-pocket payments than those not seen by doctors and the non-insured. ${ }^{92,93}$

\section{Street Level Bureaucracy}

The elements of SLB, extracted using the 2010 edition of Lipsky's work ${ }^{103}$ are illustrated in Table 4 .

\section{Discretion}

Frontline worker discretion was an important explanatory factor for central-policy-unintended out-of-pocket payments. Health workers used their discretion to determine who got 'free' service and who paid for service. When facilities in Ghana suspended 'free' health services to insurance clients, insured pregnant women were 'rubber stamped'103 (approved) to receive free services due to strong political and global influence towards the attainment of millennium development goals. They still had to pay for the very expensive services to sustain the system. ${ }^{84}$ Some pregnant women had to pay more than other clients because they were farmers, married, uneducated, nulliparous ${ }^{80}$ or belonged to a different religion. ${ }^{83}$ This is because health workers perceived these categories as high-risk clients who made more demands on the already constrained health system or as groups that complied easily with the central-policy-unintended payments needed to maintain a functional health system. An unintended consequence of health worker differentiation between clients (worker bias). ${ }^{103}$ On the other hand, clients perceived to cause less strain on resources and workload were also exempted from making central-policy-unintended out-of-pocket payments by 'creaming.' ${ }^{103}$

The autonomous use of discretionary power appeared to be influenced by rationalisation and justification based on moral/ ethical lines, societal norms, informal rules, pressures from clients, individual values or the prevailing sanctions. The use of discretion created variation in implementation of policy. Vulnerable groups such as pregnant women and orphans were sometimes exempt from making out-of-pocket payments (advocacy) ${ }^{103}$ and in other cases had to pay like everyone else based on discretion. A poor rural woman who lived with her brother's orphaned children always received all services for free while others were treated with contempt and had to make payments under insurance. ${ }^{85}$ Health workers sometimes personally paid the peripheral-policy-intended bills of needy insured clients. ${ }^{60}$ Some health managers stocked medicines for insurance clients while others stocked medicines not on insurance lists for profit. ${ }^{84}$

\section{Conditions of Work}

Macro and meso-level health system and policy issues, created conditions of work that forced frontline workers to adopt 'coping' patterns of practice (Table 4). This generated peripheral-policy-unintended and peripheral-policyintended fees at a cost to clients. Agency goals and expectations were sometimes conflicting and ambiguous, such as, health workers being expected to provide "free" services despite resource constraints and reimbursement uncertainties. ${ }^{60,82,83}$ They faced daily dilemmas such as; 'do I treat an emergency case for free and not get reimbursed, charge the client for the service, refer to a distant referral centre knowing the client would default or could die on the way, or make clients buy the unavailable supplies for the procedure?'

Apart from private facilities attending to private insurance clients, all other facilities had to grapple with chronically inadequate resources mainly due to lack of funds at facility level from delayed or low insurance reimbursements and poor resource allocation. There was a lack of human resource, equipment, drug and non-drug consumables across all facility types. It was difficult to maintain or procure equipment, upgrade facilities, motivate and recruit staff. ${ }^{62,80-85,87-89}$

Facilities could not replenish their stocks due to inadequate funds, fall-out with suppliers or because the limited funds were being prioritised for other activities. ${ }^{60,62,81-85,87-89}$ These resource constraints were sometimes not so clearly evident in the papers that centred solely on private insurance..$^{86,92,93}$

Health insurance reforms generally led to increased demand for health services. The increase in utilization resulted in increased workload and waiting times in health facilities, 
especially in public than private health facilities, across South Africa, Ghana, Tanzania and Kenya..$^{60,82,83,85,87,88}$

Health workers modified the concept of their work and their clients through the creation of routines and simplifications to cope with conditions of work, conserve resources and prepare for unpredictable emergencies. Though this helped frontline workers to deal with the pressures of work, it also resulted in unintended "opportunity costs" for clients from lateness, absenteeism, strikes, disrespect and poor responsiveness (consequences of health worker alienation ${ }^{103}$ ). ${ }^{60,62,82-85,87}$ Work was modified in some cases to shorter opening hours in Tanzania, Ghana and South Africa, apparently to make time for additional administrative work..$^{82}$ Long queues ${ }^{85}$ and the provision of very little information helped control clients' behaviour. ${ }^{60}$ Health workers also sometimes rationed services to insurance clients by imposing indirect costs (waiting), ${ }^{103}$ denying services or referring ${ }^{103}$ them to other facilities where they sometimes had to pay out-of-pocket. ${ }^{60,62,83-85,87,95}$

\section{Ambiguous Policy Content}

The policy content was not always clear to all actors involved in the policy process. It was sometimes froth with misconceptions, ambiguous goal expectations, and no provision for unintended consequences. ${ }^{83}$ Ghanaian actors in health facilities, district and regional levels did not clearly understand the fund disbursement process even though they appreciated the diversity in the sources of funding for the scheme. ${ }^{83,87}$ The language of the policy was sometimes too complex for insurance clients and health workers to understand in South Africa. Clients were sometimes not sure what their benefits entailed. ${ }^{86}$ The concept of capitation was poorly understood by health workers and clients in Ghana and Tanzania. ${ }^{60,87}$ Scheme members in Tanzania also complained of poor 'benefits-communication' system. ${ }^{82}$ Waivers and exemptions could not be granted because actors did not understand the criteria for eligibility ${ }^{82,83}$ or did not know that they existed..$^{82}$ Some insured clients in Kenya made out-of-pocket payments because they did not know how to use insurance. ${ }^{60}$ This lack of understanding meant that health workers charged for services which were covered and scheme members were not sure what they had to pay or not pay for.

\section{Monopoly}

Although enrolment with an insurance scheme was supposed to provide financial access to clients, this access was limited. The few facilities available to clients controlled the types of services they received. In some cases, clients still had to make payments for services covered by the scheme, incur opportunity cost from travelling or waiting in long queues, endure contempt from health workers or pay more for responsive services in private facilities. There were instances where poor clients who were referred to other facilities due to faulty equipment or stock-outs defaulted. ${ }^{85}$ The lack of district hospitals sometimes hindered enrolment in rural areas. ${ }^{83}$ There was not much competition between health facilities and the options available to insurance clients always had limitations. Opting out or using their power of choice was not effective as sanctions for improvement in the health system.
Practical Norms (Olivier de Sardan) and Corruption (Vian's Theory)

\section{Practical Norms}

There were instances where health workers abused power for their personal or collective gain rather than as coping behaviour. It was sometimes difficult to separate out practical norms from corruption. The different types of payments identified in this synthesis which sometimes reflected widespread "practical norms" and sometimes isolated corrupt behaviour included levies, commissions, misappropriation, unwarranted fee for service and gratuity. Where these central-policy-unintended payments were influenced by the informal rules of practical norms (Table 5); they overlapped with and were similar to some patterns of practice of street level bureaucrats in some cases making it difficult to clearly separate out the dominant behaviour drivers.

Generally, the elements of practical norms and corruption seemed to run through various levels of the health system and interacted with each other. They were evident in all the countries included in this synthesis. Insured clients lamented about its infectious nature, "...there is corruption in Kenya, corruption is everywhere...." 85

Health insurance staff took advantage of their privileged position as public officials and used their discretionary power to 'levy' other actors in the health system. They would sometimes delay reimbursement to private pharmacies that refused to pay "kickbacks." $60,83-85,88$ These pharmacies in turn used their discretionary power to opt-out of the scheme or refused to serve insurance clients. ${ }^{84}$ Health workers on the other hand also demanded bribes and unofficial fees (levy) from clients. Midwives, who were seen as very essential health workers because of the need to improve maternal health indicators globally, were observed by Witter et $\mathrm{al}^{87}$ to have acted with 'impunity', withdrawing services in peripheral facilities when they were cautioned against corrupt practices. They collected drug consumables from facility pharmacies (misappropriation) for personal gain, levied clients ${ }^{83}$ and demanded 'gratuity' from mothers who delivered in health facilities at significant cost to clients. ${ }^{87}$ Dispensary staff in Kenya audaciously bargained with clients over the cost of medicines covered by insurance. Although the clients complained and were opposed to these corrupt practices, they too were sometimes partakers, paying 'commissions' to skip long queues since there was no other way to get by the 'system.' ${ }^{\text {'5 }}$

\section{Vian's Theory: Transparency}

Actors in most of the countries reviewed did not clearly understand how the various insurance policies worked. Information dissemination and clarity was generally poor. Actors from national level to the frontline did not understand why reimbursements were delayed..$^{60,85-87}$ No explanations were given for delayed reimbursements in the countries affected. In South Africa, for example, neither regulators nor pharmacists could explain why insured clients had to co-pay for medicines. The co-payment arrangements were described as 'unpredictable,' 'inconsistent,' 'complicated,' 'dynamic' and 'not transparent.' To increase profit, pharmacists failed 
Table 5. Elements of Practical Norms and 'Corruption Complex' Identified in the Articles

\begin{tabular}{|c|c|c|c|c|c|c|c|c|c|c|}
\hline \multirow[b]{2}{*}{ Reference } & \multicolumn{10}{|c|}{ Elements of Practical Norms } \\
\hline & $\begin{array}{l}\text { Systemic } \\
\text { Corruption }\end{array}$ & Impunity & $\begin{array}{c}\text { Contempt for } \\
\text { Anonymous Users }\end{array}$ & $\begin{array}{l}\text { Formal Versus } \\
\text { the Real }\end{array}$ & $\begin{array}{l}\text { Each-One-for- } \\
\text { Oneself-ism }\end{array}$ & $\begin{array}{l}\text { Rooms of } \\
\text { Suspicion }\end{array}$ & ‘Privilegism' & $\begin{array}{l}\text { A Double } \\
\text { Language }\end{array}$ & Clientelism & $\begin{array}{l}\text { Dependence on } \\
\text { Donor Support }\end{array}$ \\
\hline Agyepong et al (2016) & $x$ & $x$ & $x$ & $x$ & & & & $x$ & & \\
\hline Aidam et al (2016) & $\mathrm{x}$ & & & & & & & & & \\
\hline Aryeetey et al (2016) & $\mathrm{x}$ & & & & & & & & & \\
\hline Ashigbie et al (2016) & $\mathrm{x}$ & $\mathrm{x}$ & & & $\mathrm{x}$ & $\mathrm{x}$ & $\mathrm{x}$ & & & \\
\hline \multicolumn{11}{|l|}{ Attia-Konan et al (2019) } \\
\hline \multicolumn{11}{|l|}{ Beogo et al (2016) } \\
\hline \multicolumn{11}{|l|}{ Dalaba et al (2014) } \\
\hline \multicolumn{11}{|l|}{ Dalinjong et al (2017) } \\
\hline \multicolumn{11}{|l|}{ Dalinjong et al ${ }^{a}(2018)$} \\
\hline Dalinjong et al (2018) & & & & $\mathrm{x}$ & & & & & & \\
\hline Kabia et al (2019) & $x$ & $x$ & $x$ & $x$ & & & & $\mathrm{x}$ & $\mathrm{x}$ & \\
\hline \multicolumn{11}{|l|}{ Kusi et al (2015) } \\
\hline Mpanza et al (2019) & & & $\mathrm{x}$ & $\mathrm{x}$ & $\mathrm{x}$ & $\mathrm{x}$ & & & $\mathrm{x}$ & \\
\hline Nguyen et al (2011) & $\mathrm{x}$ & $\mathrm{x}$ & & $\mathrm{x}$ & & & & & & \\
\hline \multicolumn{11}{|l|}{ Siita et al (2019) } \\
\hline Suchman (2018) & $\mathrm{x}$ & $\mathrm{x}$ & & & & $\mathrm{x}$ & $\mathrm{x}$ & & & \\
\hline Witter et al (2013) & $\mathrm{x}$ & & & $\mathrm{x}$ & & $\mathrm{x}$ & $\mathrm{x}$ & & & $\mathrm{x}$ \\
\hline Total number of articles with the practical norm present & 8 & 5 & 3 & 6 & 2 & 4 & 3 & 2 & 2 & 1 \\
\hline
\end{tabular}

a Used to differentiate the 2018 papers by same author. 
to explain the cost-benefits of cheaper generic medicines to clients who had to co-pay on account of brand loyalty. ${ }^{86}$ In all the countries, it was as if this confusion was needed to generate placid acceptance of the gap in policy implementation.

\section{Vian's Theory: Enforcement}

Health insurance policies generally appeared to be poorly regulated. There was no evidence of sanctions for corruption, and coping strategies were not streamlined. ${ }^{60,83-87,93}$ There was no mechanism in place to monitor the "provider shopping" by clients that put undue strain on health system resources in Ghana. ${ }^{84}$ Private insurance holders were charged indiscriminately for services leading to co-payments in South Africa and bills that were about three times that of the noninsured in Burkina Faso. ${ }^{86,93}$ It appeared the regulators did not have the moral justification to call perpetrators to order since the charging of central-policy-unintended fees sometimes appeared to keep defunct health systems functional.

\section{Vian's Theory: Citizen Voice}

There was very little evidence of citizen's engagement in the policy process. They had limited power to influence policy because they lacked clear knowledge of their insurance benefits, were non-voluntary, were sometimes poor and were afraid of being mistreated. Without appropriate and effective complaint mechanisms, clients were not enthusiastic about complaining. ${ }^{85}$ Even rich private insurance clients were reluctant to ask questions about their payments because they just wanted to get better and were afraid that they would not understand the complex explanations. ${ }^{86}$ Therefore, citizen voice could not ensure answerability and enforcement of sanctions.

\section{Discussion}

Although a few studies have explored central-policyunintended out-of-pocket payments at point-of-service use from the perspective of coping behaviour and/ or corruption in SSA, ${ }^{54,104,105}$ this study is different in its effort to synthesize the existing literature from the perspective of a policy implementation gap in the context of health insurance reforms. It is an important effort at this time given the context of SDG-3 and the push for UHC, and to leave no one behind.

This study draws on Vian's framework, SLB theory and the concept of practical norms to help health policy actors understand the policy implementation gap of central-policyunintended out-of-pocket payments by health insurance clients for insured services in SSA. The use of frontline discretionary power broadly leads to coping or corruption in the expression of this policy implementation gap. Corruption might be for personal gain or as part of a "corruption complex" influenced by practical norms. Powerless health insurance clients lacked expert knowledge on health and the content of their insurance policies. They did not trust that the health system had their interest at heart. They were afraid, voiceless and paid bribes as their expression of power to attain that which is their right (health). Monopoly or competition, citizen voice, transparency, enforcement, and the use of discretion affects the expression of accountability in the health system. Proper accountability at all levels of the health system eventually affects the use of discretionary power in the expression of practical norms or street level bureaucrats' decisions, actions and inactions in policy implementation.

Context matters, and macro and meso-level contextual factors affect the experience of clients at the frontline of the health system. Accountable leadership and governance at the macro level of country health systems translates into equitable allocation and prioritisation of resources for health systems, formal/informal norms and values within the health system such as trust. These affect the rationalisation and justification of frontline workers' behaviour.

Despite an increasing push for health insurance - whether social, tax funded, community-based or mixed-type financing reforms in SSA, attention is not being paid to the importance of a holistic understanding of the health systems and contexts for these reforms. Much of the push appears to be from a top-down perspective to policy-making and yet most of the conditions stipulated by Hogwood and Gunn ${ }^{64}$ for effective policy implementation via the top-down approach were not met by the countries in this narrative synthesis review. The bottom-up expression of the policy that is occurring at implementation level appears to be conveniently ignored. Despite their importance for successful interventions in complex system, effective stakeholder engagement and voice, including frontline workers in co-production of the design and implementation of policy, clear policy statements, and fitting of design to context - including resources for implementation do not seem to feature as much in the design considerations as the more technical econometric issues. And yet the literature shows that frontline providers and managers' discretionary power has effect on policy implementation in LMICs. ${ }^{106}$ Policy ambitions were also bigger than the resources available despite the literature on the coping behaviour that results when what the policy dictates is not possible on the resources provided. Insufficient health financing, invariably resulted in central-policy-unintended payments for sustainability and sometimes for personal gain as described by Gaal et al. ${ }^{107} \mathrm{~A}$ review on informal payments for maternal health services also revealed that poor health financing by government decreased trust and forced health workers to adopt coping strategies which could be formal or informal. ${ }^{108}$ Health workers were not just behaving badly by charging out-of-pocket payments for personal gain but in some cases were trying to make sense out of their reality by coping.

The lack of transparent leadership and governance as well as accountability as a health system value influenced the implementation of insurance policies and the creation of the policy implementation gap of unintended out-ofpocket payments. Accountability puts limits on the abusive use of discretionary power at all levels of the health system. It informs judicious allocation of resources, transparency in policy processes, fosters trust as a health system value and influences the rationalisation and justification of actors' actions. Accountability is expressionless without appropriate sanctions and the application of sanctions without appropriate allocation of resources for implementation can result in unintended consequences. Other studies in LMICs 
also propose the lack of accountability as a cause of informal payments and corruption. ${ }^{54,109}$

The cultural norm of gift giving that influenced the demand of gratuity by midwives in this study was described by other studies proposing that the cost imposed by these gifts on the patient and relatives could make them legal or illegal..$^{54,110,111}$ In the context of this study, this practical norm appeared to be quite expensive to some households and bordered on corruption.

Although there is evidence that other LMICs in SSA are moving towards UHC through health insurance reforms, ${ }^{112}$ coping behaviour, practical norms and corruption explain the out-of-pocket payments not stipulated by the policies that end up limiting access to health ${ }^{113}$ and puts the poor at a disadvantage ${ }^{114}$ despite lofty policy intents to achieve universality and equity.

We recommend that policy-makers adopt an integrated iterative approach to policy formulation, implementation and evaluation with extensive stakeholder involvement at all levels. Policy content should be clearly communicated to ensure actor empowerment and involvement. Reforms should occur in tandem with the scale-up of health resources and infrastructure to meet demand. Moral reflexive leaders ${ }^{115}$ should be tasked to transform health systems. ${ }^{116}$

\section{Limitations}

This study adds to the literature on corruption and policy implementation gaps in LMICs. It drew on three theoretical concepts to explain a complex policy implementation gap because a single theory could not suffice. For example, SLB could not explain out-of-pocket payments under private health insurance. Although we identified overlaps in theory tenets such as the expression of contempt for anonymous users (practical norm) which could also be explained under the consequences of alienation and worker bias in SLB, the theories did not exhaustively explore all the influences on frontline discretionary power leading to policy implementation gaps. Further empirical studies drawing on other theories such as actor interface analysis ${ }^{117}$ or contextual interaction theory ${ }^{118,119}$ could be beneficial.

The inclusion criteria employed for the selection of literature might have excluded some papers of relevance to this review. The selected papers were from six countries in SSA and this might limit the generalisability of this research to other countries. This study raises further questions and sets the stage for further empirical studies looking at the role of leaders and managers in the creation of this policy implementation gap, how much central-policy-unintended out-of-pocket payments are being made by insured clients, the role of trust, power and accountability in propounding this implementation gap, why the reimbursement delays, if the referrals were 'rents' or 'coping', and which cadre of health workers are involved in charging central-policy-unintended out-of-pocket payments. The cross-sectional studies gave limited information on the 'why' of central-policy-unintended out-of-pocket payments from Francophone countries. ${ }^{92,93}$ In addition to the Francophone studies, only South Africa addressed private social health insurance. ${ }^{82,86}$ This limits the study's generalisability to private insurance schemes and francophone countries.

\section{Conclusion}

The policy implementation gap of out-of-pocket payments for health services covered by insurance is real in SSA. This implementation gap works against equity and UHC. The poor and vulnerable groups who are supposed to benefit the most from health insurance reforms in terms of financial risk protection and financial access to health are the biggest losers. A continued top-down approach to health financing reform and UHC policy is likely to continue to face implementation gaps. It is important to explore bottom-up approaches recognizing issues related to accountability, trust, coping behaviour and practical norms in the face of unrealistic and sometimes conflicting policy dictates in relation to resources available and other policies that also have to be implemented; as well as corruption, rather than a simplistic assumption that non-compliance and/or fees unintended by the policy are all corruption.

\section{Acknowledgements}

This study was funded and supported by the Alliance for Health Policy and Systems Research, Health Policy Analysis Fellowship programme under the World Health Organisation. The primary author received invaluable mentoring and peer support from the fellows and mentors of the programme as part of the 2017 cohort.

The IDRC funded Consortium for Mothers, Children, Adolescents and Health Policy Systems and Strengthening project supported this work through sponsorship for health policy and systems research capacity building in West Africa through a pre-doctoral training program in Accra (6 weeks) in 2017 and provision of IDRC library access and its document delivery service for the literature search.

\section{Ethical issues}

This study is the first phase of a fellowship research approved by the Ghana Health Service Ethics Review Committee. Since only published peer reviewed literature was used for this research there was no requirement for ethical clearance.

\section{Competing interests}

Authors declare that they have no competing interests.

\section{Authors' contributions}

ANCDK carried out the study and was the primary author. IAA, NE and LG supportively supervised the research process. IAA edited the initial manuscript. All authors contributed to the conceptualisation of the study and the final draft.

\section{Funding}

This work was partly funded by the Alliance for Health Policy and Systems Research through the Health Policy Analysis Fellowship Programme, the IDRC funded Consortium for Mothers, Children, Adolescents and Health Policy Systems and Strengthening project, and the Ghana Health Service's paid study leave award programme.

\section{Authors' affiliations}

${ }^{1}$ Faculty of Public Health, Ghana College of Physicians and Surgeons, Accra, Ghana. ${ }^{2}$ Ghana Health Service, Accra, Ghana. ${ }^{3}$ Research and Development Division, Ghana Health Service, Accra, Ghana. ${ }^{4}$ School of Public Health and Family Medicine, University of Cape Town, Cape Town, South Africa. ${ }^{5}$ Department of Global Health and Development, London School of Hygiene and Tropical Medicine, London, UK. 
Supplementary files

Supplementary file 1. Quality Criteria for Selection of Papers for the Study.

\section{References}

1. Gauld R, Blank R, Burgers J, et al. The World Health Report 2008-Primary healthcare: how wide is the gap between its agenda and implementation in 12 high-income health systems? Healthc Policy. 2012;7(3):38-58. doi:10.12927/hcpol.2013.22778

2. Abiiro GA, De Allegri M. Universal health coverage from multiple perspectives: a synthesis of conceptual literature and global debates. BMC Int Health Hum Rights. 2015;15:17. doi:10.1186/s12914-015-0056-9

3. Colombo F, Tapay N. Private Health Insurance in OECD Countries: The Benefits and Costs for Individuals and Health Systems. OECD Health Working Papers. 2004. http://www.oecd.org/dataoecd/34/56/33698043. pdf.

4. United Nations. Transforming Our World: The 2030 Agenda for Sustainable Development. New York: United Nations; 2015. doi:10.1201/b20466-7

5. Mclntyre D, Ranson MK, Aulakh BK, Honda A. Promoting universal financial protection: evidence from seven low- and middle-income countries on factors facilitating or hindering progress. Health Res Policy Syst. 2013;11:36. doi:10.1186/1478-4505-11-36

6. Tangcharoensathien V, Limwattananon S, Patcharanarumol W, Thammatacharee J, Jongudomsuk P, Sirilak S. Achieving universal health coverage goals in Thailand: the vital role of strategic purchasing. Health Policy Plan. 2015;30(9):1152-1161. doi:10.1093/heapol/czu120

7. OECD Better policies for better lives. Health System Characteristics Survey 2016. Costa Rica.; 2016. http://www.oecd.org/els/health-systems/ OECD-HSC-Survey-2016-CostaRica-Comments.pdf. Accessed January 28, 2021.

8. Casas A, Vargas $\mathrm{H}$. The health system in Costa Rica: toward a National Health Service. J Public Health Policy. 1980;1(3):258-279. doi:10.2307/3342089

9. OECD. Proposal for a Taxonomy of Health Insurance. OECD; 2004. https://www.oecd.org/health/health-systems/31916207.pdf.

10. Doethinchem O, Carrin G, Evans D. Thinking of Introducing Social Health Insurance? Ten Questions. Geneva: WHO; 2010. https://www.who.int/ healthsystems/topics/financing/healthreport/26_10Q.pdf?ua=1.

11. Jost TS. Private or public approaches to insuring the uninsured: lessons from international experience with private insurance. $N$ Y Univ Law Rev. 2001;76(2):419-492.

12. Sekhri N, Savedoff W. Private health insurance: implications for developing countries. Bull World Health Organ. 2005;83(2):127-134.

13. Carrin G. Community Based Health Insurance Schemes in Developing Countries: Facts, Problems and Perspectives. Geneva; 2003. https:// apps.who.int//iris/bitstream/handle/10665/69023/EIP_FER_DP.E_03.1.pd f?sequence=1\&isAllowed=y. Accessed August 23, 2020.

14. WHO. Out-of-Pocket Payments, User Fees and Catastrophic Expenditure. WHO; 2016. http://www.who.int/health_financing/topics/financial-protection/out-of-pocket-payments/en/.

15. Xu K, Evans DB, Kawabata K, Zeramdini R, Klavus J, Murray CJ. Household catastrophic health expenditure: a multicountry analysis. Lancet. 2003;362(9378):111-117. doi:10.1016/s0140-6736(03)13861-5

16. Barasa EW, Maina T, Ravishankar N. Assessing the impoverishing effects, and factors associated with the incidence of catastrophic health care payments in Kenya. Int J Equity Health. 2017;16(1):31. doi:10.1186/ s12939-017-0526-x

17. Akazili J, Ataguba JE, Kanmiki EW, et al. Assessing the impoverishment effects of out-of-pocket healthcare payments prior to the uptake of the National Health Insurance Scheme in Ghana. BMC Int Health Hum Rights. 2017;17(1):13. doi:10.1186/s12914-017-0121-7

18. Myint ANM, Liabsuetrakul T, Htay TT, Wai MM, Sundby J, Bjertness E. Impoverishment and catastrophic expenditures due to out-of-pocket payments for antenatal and delivery care in Yangon Region, Myanmar: a cross-sectional study. BMJ Open. 2018;8(11):e022380. doi:10.1136/ bmjopen-2018-022380

19. Shubha D, Kaur N, Mahabalaraju D. Health care seeking behaviour and out-of-pocket health expenditure for under-five illnesses in urban slums of Davangere, India. BMJ Glob Health. 2016;1(Suppl 1):A11. doi:10.1136/ bmjgh-2016-EPHPabstracts.14

20. Abdulmalik J, Olayiwola S, Docrat S, Lund C, Chisholm D, Gureje O. Sustainable financing mechanisms for strengthening mental health systems in Nigeria. Int J Ment Health Syst. 2019;13:38. doi:10.1186/ s13033-019-0293-8
21. Homer CSE, Castro Lopes S, Nove A, et al. Barriers to and strategies for addressing the availability, accessibility, acceptability and quality of the sexual, reproductive, maternal, newborn and adolescent health workforce: addressing the post-2015 agenda. BMC Pregnancy Childbirth. 2018;18(1):55. doi:10.1186/s12884-018-1686-4

22. Elwell-Sutton TM, Jiang CQ, Zhang WS, et al. Inequality and inequity in access to health care and treatment for chronic conditions in China: the Guangzhou Biobank Cohort Study. Health Policy Plan. 2013;28(5):467479. doi:10.1093/heapol/czs077

23. Fadlallah R, El-Jardali F, Hemadi $\mathrm{N}$, et al. Barriers and facilitators to implementation, uptake and sustainability of community-based health insurance schemes in low- and middle-income countries: a systematic review. Int J Equity Health. 2018;17(1):13. doi:10.1186/s12939-018-07214

24. Pettigrew LM, Mathauer I. Voluntary Health Insurance expenditure in lowand middle-income countries: exploring trends during 1995-2012 and policy implications for progress towards universal health coverage. Int $J$ Equity Health. 2016;15:67. doi:10.1186/s12939-016-0353-5

25. Khan JAM, Ahmed S, Evans TG. Catastrophic healthcare expenditure and poverty related to out-of-pocket payments for healthcare in Bangladeshan estimation of financial risk protection of universal health coverage. Health Policy Plan. 2017;32(8):1102-1110. doi:10.1093/heapol/czx048

26. Adisa $O$. Erratum to: investigating determinants of catastrophic health spending among poorly insured elderly households in urban Nigeria. Int $\mathrm{J}$ Equity Health. 2015;14:104. doi:10.1186/s12939-015-0241-4

27. Nandi S, Schneider H, Dixit P. Hospital utilization and out of pocket expenditure in public and private sectors under the universal government health insurance scheme in Chhattisgarh State, India: lessons for universal health coverage. PLoS One. 2017;12(11):e0187904. doi:10.1371/journal. pone.0187904

28. Alhassan RK, Nketiah-Amponsah E, Arhinful DK. A review of the National Health Insurance Scheme in Ghana: what are the sustainability threats and prospects? PLoS One. 2016;11(11):e0165151. doi:10.1371/journal. pone. 0165151

29. O'Neill KM, Mandigo M, Pyda J, et al. Out-of-pocket expenses incurred by patients obtaining free breast cancer care in Haiti: a pilot study. Surgery. 2015;158(3):747-755. doi:10.1016/j.surg.2015.04.040

30. Asheela S, Qadiri GJ, Shet N, Sharma P. A study on out of pocket expenditure among the urology patients covered under health schemes in a teaching hospital. Int J Community Med Public Health. 2019;6(9):38923898. doi:10.18203/2394-6040.ijcmph20193989

31. Gotsadze G, Zoidze A, Rukhadze N. Household catastrophic health expenditure: evidence from Georgia and its policy implications. BMC Health Serv Res. 2009;9:69. doi:10.1186/1472-6963-9-69

32. Mclntyre D, Thiede M, Dahlgren G, Whitehead M. What are the economic consequences for households of illness and of paying for health care in low- and middle-income country contexts? Soc Sci Med. 2006;62(4):858865. doi:10.1016/j.socscimed.2005.07.001

33. Agyepong IA, Nagai RA. "We charge them; otherwise we cannot run the hospital" front line workers, clients and health financing policy implementation gaps in Ghana. Health Policy. 2011;99(3):226-233. doi:10.1016/j.healthpol.2010.09.018

34. Anderson GA, Ilcisin L, Kayima P, et al. Out-of-pocket payment for surgery in Uganda: the rate of impoverishing and catastrophic expenditure at a government hospital. PLoS One. 2017;12(10):e0187293. doi:10.1371/ journal.pone.0187293

35. Okoroh J, Essoun S, Seddoh A, et al. Evaluating the impact of the National Health Insurance Scheme of Ghana on out of pocket expenditures: a systematic review. BMC Health Serv Res. 2018;18(1):426. doi:10.1186/ s12913-018-3249-9

36. Kwakye E. Household health care expenditure and catastrophic payments: evidence from the Ghana Living Standards Survey V. J Appl Bus Econ. 2017;19(3):29-50.

37. Brinda EM, Andrés AR, Enemark U. Correlates of out-of-pocket and catastrophic health expenditures in Tanzania: results from a national household survey. BMC Int Health Hum Rights. 2014;14:5. doi:10.1186/1472-698x-14-5

38. Mclntyre D, Garshong B, Mtei G, et al. Beyond fragmentation and towards universal coverage: insights from Ghana, South Africa and the United Republic of Tanzania. Bull World Health Organ. 2008;86(11):871-876. doi:10.2471/blt.08.053413

39. Akazili J, Gyapong J, Mclntyre D. Who pays for health care in Ghana? Int J Equity Health. 2011;10:26. doi:10.1186/1475-9276-10-26 
40. Mtei G, Makawia S, Ally M, Kuwawenaruwa A, Meheus F, Borghi J. Who pays and who benefits from health care? An assessment of equity in health care financing and benefit distribution in Tanzania. Health Policy Plan. 2012;27 Suppl 1:i23-34. doi:10.1093/heapol/czs018

41. Mahumud RA, Sarker AR, Sultana M, Islam Z, Khan J, Morton A. Distribution and determinants of out-of-pocket healthcare expenditures in Bangladesh. J Prev Med Public Health. 2017;50(2):91-99. doi:10.3961/ jpmph.16.089

42. Hurst JW. Reforming health care in seven European nations. Health Aff (Millwood). 1991;10(3):7-21. doi:10.1377/hlthaff.10.3.7

43. Centers for Medicare \& Medicaid Services. Cost Sharing Out of Pocket Costs. Medicaid.gov. https://www.medicaid.gov/medicaid/cost-sharing/ out-of-pocket-costs/index.html. Published 2013

44. New Perspectives on Global Health Spending for Universal Health Coverage.; 2015. https://www.who.int/health_financing/topics/resourcetracking/new_perspectives_on_global_health_spending_for_uhc. pdf?ua=1. Accessed March 25, 2019.

45. Hopkins S. Health Expenditure Comparisons: Low, Middle and High Income Countries. Vol 3.; 2010. https://pdfs.semanticscholar.org/53e6/ ccd75f6c1c87548d571f565798dddb5a2c65.pdf. Accessed March 25, 2019.

46. Saksena P, Xu K, Elovainio R, Perrot J. Utilization and expenditure at public and private facilities in 39 low-income countries. Trop Med Int Health. 2012;17(1):23-35. doi:10.1111/j.1365-3156.2011.02894.x

47. Odeyemi IA. Community-based health insurance programmes and the National Health Insurance Scheme of Nigeria: challenges to uptake and integration. Int J Equity Health. 2014;13:20. doi:10.1186/1475-9276-13-20

48. Murphy A, Jakab M, McKee M, Richardson E. Persistent low adherence to hypertension treatment in Kyrgyzstan: how can we understand the role of drug affordability? Health Policy Plan. 2016;31(10):1384-1390. doi:10.1093/heapol/czw080

49. Mondal S, Kanjilal B, Peters DH, Lucas H. Catastrophic out-of-pocket payment for health care and its impact on households: experience from West Bengal, India. Economics Bulletin. 2014;34(2:1303-1316.

50. Chu TB, Liu TC, Chen CS, Tsai YW, Chiu WT. Household out-ofpocket medical expenditures and National Health Insurance in Taiwan: income and regional inequality. BMC Health Serv Res. 2005;5:60. doi:10.1186/1472-6963-5-60

51. Fu W, Zhao S, Zhang Y, Chai P, Goss J. Research in health policy making in China: out-of-pocket payments in Healthy China 2030. BMJ. 2018;360:k234. doi:10.1136/bmj.k234

52. Vian T. Review of corruption in the health sector: theory, methods and interventions. Health Policy Plan. 2008;23(2):83-94. doi:10.1093/heapol/ czm048

53. Hutchinson E, Balabanova D, McKee M. We need to talk about corruption in health systems. Int $J$ Health Policy Manag. 2019;8(4):191-194. doi:10.15171/ijhpm.2018.123

54. Onwujekwe O, Agwu P, Orjiakor C, et al. Corruption in Anglophone West Africa health systems: a systematic review of its different variants and the factors that sustain them. Health Policy Plan. 2019;34(7):529-543. doi:10.1093/heapol/czz070

55. Khodamoradi A, Rashidian A, Daryabeygi-Khotbehsara R, Aghlmand S. Evaluation of informal payments to health care professionals and the influential factors in Urmia city hospitals, Iran. J Med Ethics Hist Med. 2018;11:7.

56. Killingsworth JR, Hossain N, Hedrick-Wong $\mathrm{Y}$, Thomas SD, Rahman A, Begum T. Unofficial fees in Bangladesh: price, equity and institutional issues. Health Policy Plan. 1999;14(2):152-163. doi:10.1093/ heapol/14.2.152

57. Onyeajam DJ, Xirasagar S, Khan MM, Hardin JW, Odutolu O. Antenatal care satisfaction in a developing country: a cross-sectional study from Nigeria. BMC Public Health. 2018;18(1):368. doi:10.1186/s12889-0185285-0

58. Cohen N. How culture affects street-level bureaucrats' bending the rules in the context of informal payments for health care: the Israeli case. Am Rev Public Adm. 2018;48(2):175-187. doi:10.1177/0275074016665919

59. Murphy A, Mahal A, Richardson E, Moran AE. The economic burden of chronic disease care faced by households in Ukraine: a cross-sectional matching study of angina patients. Int $J$ Equity Health. 2013;12:38. doi:10.1186/1475-9276-12-38

60. Suchman L. Accrediting private providers with National Health Insurance to better serve low-income populations in Kenya and Ghana: a qualitative study. Int J Equity Health. 2018;17(1):179. doi:10.1186/s12939-0180893-y

61. Kanmiki EW, Bawah AA, Phillips JF, et al. Out-of-pocket payment for primary healthcare in the era of National Health Insurance: evidence from northern Ghana. PLoS One. 2019;14(8):e0221146. doi:10.1371/journal. pone.0221146

62. Dalinjong PA, Wang AY, Homer CSE. Has the free maternal health policy eliminated out of pocket payments for maternal health services? views of women, health providers and insurance managers in Northern Ghana. PLoS One. 2018;13(2):e0184830. doi:10.1371/journal.pone.0184830

63. Sabatier P, Mazmanian D. The conditions of effective implementation: a guide to accomplishing policy objectives. Policy Anal. 1979;5(4):481-504.

64. Hogwood BW, Gunn AL. Policy Analysis for the Real World. Oxford University Press; 1984.

65. Walt G, Gilson L. Reforming the health sector in developing countries: the central role of policy analysis. Health Policy Plan. 1994;9(4):353-370. doi:10.1093/heapol/9.4.353

66. Ramani S, Sivakami M, Gilson L. How context affects implementation of the Primary Health Care approach: an analysis of what happened to primary health centres in India. BMJ Glob Health. 2018;3(Suppl 3):e001381. doi:10.1136/bmjgh-2018-001381

67. Lehmann $U$, Gilson L. Actor interfaces and practices of power in a community health worker programme: a South African study of unintended policy outcomes. Health Policy Plan. 2013;28(4):358-366. doi:10.1093/ heapol/czs066

68. Lipsky M. Toward a Theory of Street-Level Bureaucracy. New York: University of Wisconsin; 1969.

69. Olivier de Sardan JP. Development, governance and reforms: studying practical norms in the delivery of public goods and services. In: Hagberg S, ed. Ethnographic Practice and Public Aid: Methods and Meanings in Development Cooperation. Acta Universitatis Upsaliensis; 2009.

70. de Sardan JPO. Practical norms: Informal regulations within public bureaucracies (in Africa and beyond). Real Gov Pract Norms Sub-Saharan Africa Game Rules. 2015;7:19-62. doi:10.4324/9781315723365-2

71. UNDP. UNDP launches study on income inequality in sub-Saharan Africa. https://www.undp.org/content/undp/en/home/presscenter/pressreleases/2017/09/21/undp-launches-study-on-income-inequality-in-sub-saharan-africa.html. Published September 21, 2017. Accessed December 8, 2020.

72. Alkire $S$, Conceição $P$, Calderón $C$, et al. Charting Pathways out of Multidimensional Poverty: Achieving the SDGs.; 2020. http://hdr.undp. organdhttps//ophi.org.uk/multidimensional-poverty-index/. Accessed January 26, 2021.

73. World Health Organization Regional Report for Africa. Global Health Observatory. World Health Organisation. https://www.who.int/data/gho. Accessed January 21, 2021.

74. United Nations Development Programme. Human Development Report 2020. The next Frontier: Human Development and the Anthropocene. New York; 2020. http://hdr.undp.org. Accessed January 26, 2021.

75. Rodgers $M$, Sowden A, Petticrew $M$, et al. Testing methodological guidance on the conduct of narrative synthesis in systematic reviews: effectiveness of interventions to promote smoke alarm ownership and function. Evaluation. 2009;15(1):49-73. doi:10.1177/1356389008097871

76. Popay J, Roberts H, Sowden A, et al. Guidance on the Conduct of Narrative Synthesis in Systematic Reviews: A Product from the ESRC Methods Programme. Lancaster University; 2006. doi:10.13140/2.1.1018.4643

77. Arai L, Britten N, Popay J, et al. Testing methodological developments in the conduct of narrative synthesis: a demonstration review of research on the implementation of smoke alarm interventions. Evid Policy. 2007;3(3):361-383. doi:10.1332/174426407781738029

78. Ring N, Ritchie K, Mandava L, Jepson R. A Guide to Synthesising Qualitative Research for Researchers Undertaking Health Technology Assessments and Systematic Reviews. NHS Quality Improvement Scotland; 2011.

79. Lucas PJ, Baird J, Arai L, Law C, Roberts HM. Worked examples of alternative methods for the synthesis of qualitative and quantitative research in systematic reviews. BMC Med Res Methodol. 2007;7:4 doi:10.1186/1471-2288-7-4

80. Dalinjong PA, Wang AY, Homer CSE. The operations of the free maternal care policy and out of pocket payments during childbirth in rural Northern Ghana. Health Econ Rev. 2017;7(1):41. doi:10.1186/s13561-017-0180-4 81. Dalinjong PA, Wang AY, Homer CSE. The implementation of the free 
maternal health policy in rural Northern Ghana: synthesised results and lessons learnt. BMC Res Notes. 2018;11(1):341. doi:10.1186/s13104018-3452-0

82. Macha J, Harris B, Garshong B, et al. Factors influencing the burden of health care financing and the distribution of health care benefits in Ghana, Tanzania and South Africa. Health Policy Plan. 2012;27 Suppl 1:i46-54. doi:10.1093/heapol/czs024

83. Agyepong IA, Abankwah DN, Abroso A, et al. The "Universal" in UHC and Ghana's National Health Insurance Scheme: policy and implementation challenges and dilemmas of a lower middle income country. BMC Health Serv Res. 2016;16(1):504. doi:10.1186/s12913-016-1758-y

84. Ashigbie PG, Azameti D, Wirtz VJ. Challenges of medicines management in the public and private sector under Ghana's National Health Insurance Scheme - a qualitative study. J Pharm Policy Pract. 2016;9:6. doi:10.1186/ s40545-016-0055-9

85. Kabia E, Mbau R, Oyando R, et al. "We are called the et cetera": experiences of the poor with health financing reforms that target them in Kenya. Int J Equity Health. 2019;18(1):98. doi:10.1186/s12939-0191006-2

86. Mpanza NM, Bradley H, Laing R. Reasons why insured consumers copay for medicines at retail pharmacies in Pretoria, South Africa. Afr J Prim Health Care Fam Med. 2019;11(1):e1-e6. doi:10.4102/phcfm.v11i1.1878

87. Witter S, Garshong B, Ridde V. An exploratory study of the policy process and early implementation of the free NHIS coverage for pregnant women in Ghana. Int J Equity Health. 2013;12:16. doi:10.1186/1475-9276-12-16

88. Nguyen HT, Rajkotia Y, Wang $\mathrm{H}$. The financial protection effect of Ghana National Health Insurance Scheme: evidence from a study in two rural districts. Int J Equity Health. 2011;10:4. doi:10.1186/1475-9276-10-4

89. Kusi A, Hansen KS, Asante FA, Enemark U. Does the National Health Insurance Scheme provide financial protection to households in Ghana? BMC Health Serv Res. 2015;15:331. doi:10.1186/s12913-015-0996-8

90. Ayindenaba Dalaba M, Akweongo $\mathrm{P}$, Aborigo $\mathrm{R}$, et al. Does the National Health Insurance Scheme in Ghana reduce household cost of treating malaria in the Kassena-Nankana districts? Glob Health Action. 2014;7:23848. doi:10.3402/gha.v7.23848

91. Aidam PW, Nketiah-Amponsah E, Kutame R. The effect of health insurance on out-of-pocket payments, catstrophic expenditures and healthcare utilization in Ghana: case of Ga South Municipality. Journal of Self-Governance and Management Economics. 2016;4(3):42-65.

92. Attia-Konan AR, Oga ASS, Touré A, Kouadio KL. Distribution of out of pocket health expenditures in a sub-Saharan Africa country: evidence from the national survey of household standard of living, Côte d'lvoire. BMC Res Notes. 2019;12(1):25. doi:10.1186/s13104-019-4048-z

93. Beogo I, Huang N, Gagnon MP, Amendah DD. Out-of-pocket expenditure and its determinants in the context of private healthcare sector expansion in sub-Saharan Africa urban cities: evidence from household survey in Ouagadougou, Burkina Faso. BMC Res Notes. 2016;9:34. doi:10.1186/ s13104-016-1846-4

94. Aryeetey GC, Westeneng J, Spaan E, Jehu-Appiah C, Agyepong IA, Baltussen R. Can health insurance protect against out-of-pocket and catastrophic expenditures and also support poverty reduction? evidence from Ghana's National Health Insurance Scheme. Int J Equity Health. 2016;15(1):116. doi:10.1186/s12939-016-0401-1

95. Siita S, Cox SE, Hanson K. Does capitation affect patient satisfaction and prevalence of out-of-pocket payments in the insured? a propensity score analysis of Ghana's demographic and health survey data. BMC Health Serv Res. 2019;19(1):732. doi:10.1186/s12913-019-4581-4

96. Faden L, Vialle-Valentin C, Ross-Degnan D, Wagner A. Active pharmaceutical management strategies of health insurance systems to improve cost-effective use of medicines in low- and middle-income countries: a systematic review of current evidence. Health Policy. 2011; 100(2-3):134-143. doi:10.1016/j.healthpol.2010.10.020

97. Mays N, Pope C. Qualitative research in health care. Assessing quality in qualitative research. BMJ. 2000;320(7226):50-52. doi:10.1136/ bmj.320.7226.50

98. Blaxter M. Criteria for the evaluation of qualitative research papers. Med Sociol. 2013;7(1):4-7.

99. Heale R, Twycross A. Validity and reliability in quantitative studies. Evid Based Nurs. 2015;18(3):66-67. doi:10.1136/eb-2015-102129

100. de Savigny D, Adam T. Systems Thinking for Health Systems
Strengthening. France: World Health Organization; 2009.

101. Berlan D, Buse K, Shiffman J, Tanaka S. The bit in the middle: a synthesis of global health literature on policy formulation and adoption. Health Policy Plan. 2014;29 Suppl 3:iii23-34. doi:10.1093/heapol/czu060

102. Blundo G, De Sardan JPO. Everyday Corruption in West Africa. In: Blundo G, De Sardan JPO, Arifari NB, Tidjan Alou M, eds. Everyday corruption and the state. Citizens and public officials in Africa. Zed Books; 2006:1-48. doi:10.5040/9781350219984.ch-003

103. Lipsky M. Street-Level Bureaucracy, 30th Ann. Ed.: Dilemmas of the Individual in Public Service. 30th Anniv. New York: Russell Sage Foundation; 2010. https://www.jstor.org/stable/10.7758/9781610446631. Accessed January 29, 2021.

104. McPake B, Asiimwe D, Mwesigye F, et al. Informal economic activities of public health workers in Uganda: implications for quality and accessibility of care. Soc Sci Med. 1999;49(7):849-865. doi:10.1016/s02779536(99)00144-6

105. Hutchinson E, McKee M, Balabanova D. What Drives Health Workers to Break the Rules and Use Public Resources for Private Gain? A Review of the Literature on sub-Saharan Africa. https://ace.soas.ac.uk/publication/ health-workers-literature-review-sub-saharan-africa/. Published 2019.

106. Gilson L, Schneider H, Orgill M. Practice and power: a review and interpretive synthesis focused on the exercise of discretionary power in policy implementation by front-line providers and managers. Health Policy Plan. 2014;29 Suppl 3:iii51-69. doi:10.1093/heapol/czu098

107. Gaal P, Belli PC, McKee M, Szócska M. Informal payments for health care: definitions, distinctions, and dilemmas. J Health Polit Policy Law. 2006;31(2):251-293. doi:10.1215/03616878-31-2-251

108. Schaaf M, Topp SM. A critical interpretive synthesis of informal payments in maternal health care. Health Policy Plan. 2019;34(3):216-229. doi:10.1093/heapol/czz003

109. Stepurko T, Pavlova M, Gryga I, Groot W. Empirical studies on informal patient payments for health care services: a systematic and critical review of research methods and instruments. BMC Health Serv Res. 2010;10:273. doi:10.1186/1472-6963-10-273

110. Balabanova D, McKee M. Understanding informal payments for health care: the example of Bulgaria. Health Policy. 2002;62(3):243-273. doi:10.1016/s0168-8510(02)00035-0

111. Ensor T. Informal payments for health care in transition economies. Soc Sci Med. 2004;58(2):237-246. doi:10.1016/s0277-9536(03)00007-8

112. Lagomarsino G, Garabrant A, Adyas A, Muga R, Otoo N. Moving towards universal health coverage: health insurance reforms in nine developing countries in Africa and Asia. Lancet. 2012;380(9845):933-943. doi:10.1016/s0140-6736(12)61147-7

113. Onwujekwe O, Agwu P, Orjiakor T, et al. Corruption in the Health Sector in Anglophone West Africa: Common Forms of Corruption and Mitigation Strategies. SOAS Consortium; 2018. https://ace.soas.ac.uk/wp-content/ uploads/2018/09/Corruption-in-the-health-sector-in-Anglophone-WAfrica_ACE-Working-Paper-005.pdf.

114. Kankeu HT, Ventelou B. Socioeconomic inequalities in informal payments for health care: an assessment of the 'Robin Hood' hypothesis in 33 African countries. Soc Sci Med. 2016;151:173-186. doi:10.1016/j. socscimed.2016.01.015

115. Hibbert $P$, Cunliffe $A$. Responsible management: engaging moral reflexive practice through threshold concepts. J Bus Ethics. 2015;127(1):177-188. doi:10.1007/s10551-013-1993-7

116. Michel J, Obrist B, Bärnighausen T, et al. What we need is health system transformation and not health system strengthening for universal health coverage to work: perspectives from a National Health Insurance pilot site in South Africa. S Afr Fam Pract (2004). 2020;62(1):e1-e15. doi:10.4102/ safp.v62i1.5079

117. Parashar R, Gawde N, Gilson L. Application of "actor interface analysis" to examine practices of power in health policy implementation: an interpretive synthesis and guiding steps. Int J Health Policy Manag. 2020. doi:10.34172/ijhpm.2020.191

118. Michel J, Chimbindi N, Mohlakoana N, et al. How and why policy-practice gaps come about: a South African universal health coverage context. $J$ Glob Health Rep. 2019;3:1-32. doi:10.29392/joghr.3.e2019069

119. Michel J, Tediosi F, Egger M, et al. Universal health coverage financing in South Africa: wishes vs reality. J Glob Health Rep. 2020;4:e2020061. doi:10.29392/001c.13509 